\title{
Stable and ultrastable heavy minerals of alluvial to nearshore marine sediments from Central Portugal: Facies related trends
}

\author{
Pedro A. Dinis*, António F. Soares \\ Geosciences Center, Department of Earth Sciences, University of Coimbra, Largo Marques de Pombal, 3000-272 Coimbra, Portugal
}

Received 17 July 2006; received in revised form 16 April 2007; accepted 18 April 2007

\begin{abstract}
The Pliocene to Pleistocene sedimentary record from the western Iberia Coastal Margin is a thin succession (maximum thickness around $70 \mathrm{~m}$ ) derived from the metamorphic and igneous Variscan Iberian Massif and from older sedimentary deposits. It comprises a wide variety of facies representative of deposition in environments ranging from inner shelf to alluvial fan. The facies are stacked in an overall regressive sequence. This sequence may be divided into lower order sequences with thin transgressive portions (not always present) and thicker prograding portions. Given the limited burial diagenetic transformation, the differences in heavy mineral (HM) assemblage can be explained by provenance, hydraulic segregation and chemical and mechanical selection. Transparent heavy minerals susceptible to acid treatment were not considered in this heavy mineral analysis. After the acid treatment, the HM signal is relatively monotonous. Except for the mica-rich assemblages in alluvial facies fed from the Variscan Iberian massif by short streams, the HM assemblages are dominated by tourmaline, andalusite, zircon and staurolite. However, it is still possible to recognize two opposite trends in HM composition linked to facies evolution. The first trend is widespread along the coastal margin, although typical of the earlier deposits. It is characterized by a vertical increase in staurolite and andalusite proportions coincident with prograding and regressive facies evolution. Relative sediment starvation during retrogradation, when compared to progradation, favoured the recycling of previous deposits, leading to higher proportions of ultrastable minerals (tourmaline, zircon and rutile). Hydraulic segregation in the nearshore zone also contributes to increased zircon content in the very fine sand fraction. The second trend is observed in stratigraphically higher sediments, deposited when environments were displaced basinward. This trend is common in relatively uplifted western sectors of the coastal margin, where sand and gravel dominate the record. It is characterized by a vertical increase in the content of ultrastable minerals (mostly tourmaline and zircon) throughout the regressive sequence. It may be explained by alluvial storage and the recycling of previous nearshore and coastal plain facies. Recycling, favoured by relative sediment starvation or low accommodation conditions, plays a major role in these HM assemblages.
\end{abstract}

(C) 2007 Elsevier B.V. All rights reserved.

Keywords: Heavy mineral; Facies; Provenance; Hydraulic segregation

\section{Introduction}

The mineralogy of siliciclastic deposits is controlled by numerous factors, such as provenance, sedimentary envi-

\footnotetext{
* Corresponding author.

E-mail address: pdinis@dct.uc.pt (P.A. Dinis).
}

ronment, diagenesis etc. Heavy mineral (HM) assemblages can be used to evaluate weathering and diagenetic evolution, approximate the paleogeographic conditions and help with stratigraphic correlations (Parfenoff et al., 1970; Mange and Maurer, 1992; Dill, 1998). HM associations of sedimentary deposits do not necessarily reflect their provenance, as they tend to be changed by 
transport and post-depositional processes (Morton and Hallsworth, 1999). The best way to estimate the depositional and post-depositional processes involved in a sedimentary deposit is through a careful facies analysis (Teichert, 1958; Walker and James, 1992).

The relations between HM assemblages and facies sequences and sequence stratigraphy have been studied by several authors (Carver and Kaplan, 1976; Friss, 1978). These relations are not well understood and are considered of great interest (Morton and Hallsworth, 1999). A parameter that seems useful in sequence stratigraphy is the apatite-tourmaline index (ATi). It has been demonstrated that the apatite content increases in transgressive and highstand deposits, while lowstand deposits tend to have higher tourmaline proportions (Morton and Hallsworth, 1999). But, to the authors' knowledge, no studies that consider sediments with stable and ultrastable HM assemblages, where apatite may be absent, have been presented. However, if second cycle deposits and low accommodation conditions prevail, the degradation of labile phases is likely to be very intense and the HM signal may be dominated by the most stable minerals at surface conditions.

The purpose of this study is to relate variations in stable (andalusite, staurolite, sillimanite, kyanite, garnet and mica) and ultrastable (tourmaline, zircon and rutile) HM abundances to facies and facies sequences of west Portuguese Pliocene-Pleistocene deposits. Chemically sensitive minerals, which are likely to have been destroyed during the laboratory acid cleaning process carried out in this study, are excluded from the analysis. The presence of intercalated sediments deposited in contrasting environments, ranging from open marine to alluvial fan deposits, allows an evaluation of the relations between HM assemblage and depositional environment. From the knowledge of HM composition in two grain-size fractions it is also possible to approximate the role of hydraulic segregation. Finally, given the variability in basement rocks and the tectonically active depositional setting, several morphostructural units with different accommodation space conditions can be outlined. Differences in tectonically related accommodation space are demonstrated to be responsible for different trends in HM composition.

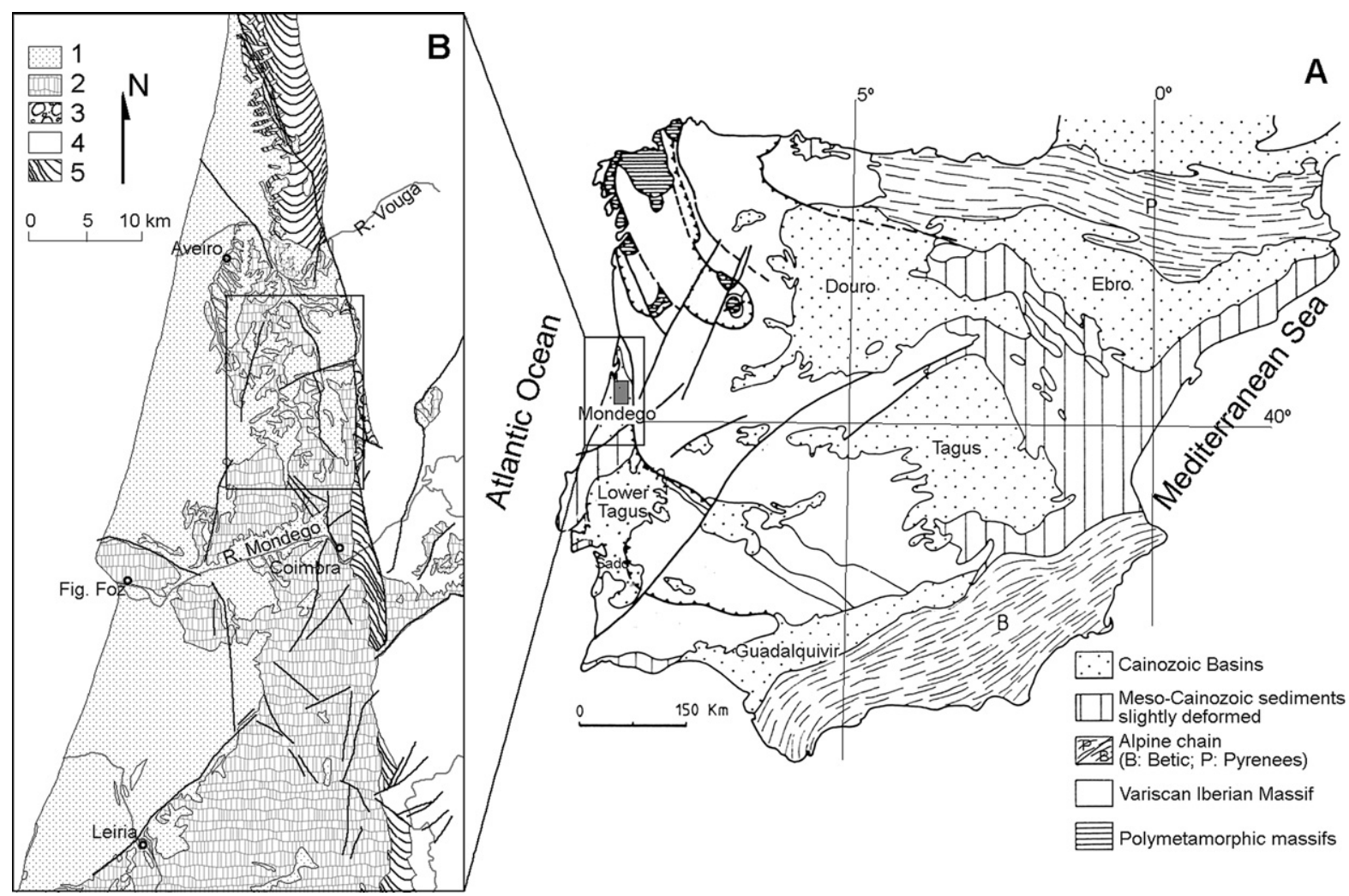

Fig. 1. Map showing Cainozoic Basins of Iberia (A) and morphostructural units in Central West of Portugal (B). 1: Cainozoic sediments; 2: Mesozoic sediments; 3: Intra-mountain Permian-Carboniferous sediments. 4: Central Iberian Zone; 5: Ossa-Morena Zone. 


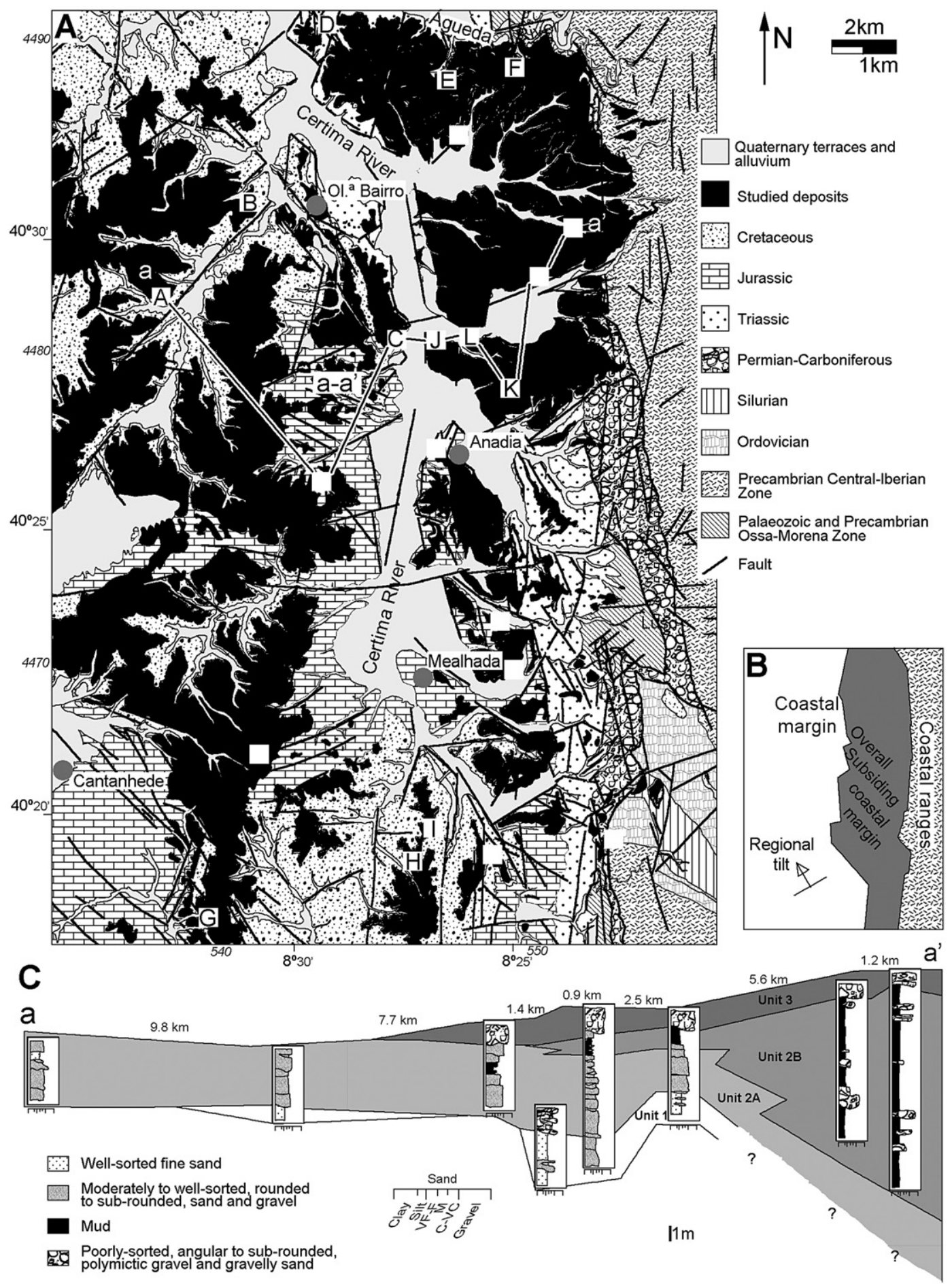

Fig. 2. Geological framework of the studied deposits. (A) Geological map of the coastal plain and surroundings (adapted from Dinis, 2004). Numbered white squares show location of graphic sedimentary logs (Fig. 5). White squares indicate the location of other sampled sections. (B) Main morphostructural units, namely the uplifted coastal ranges and the coastal margin, with a basin along the contact with the coastal ranges and an uplifted area westward; the uplifted area is tilted to the NW. (C) Lithology and geometrical relations between stratigraphic units (units 1, 2A, 2B and 3). 


\section{Geological framework}

The Pliocene to Pleistocene cover unconformably overlies Mesozoic calcareous and siliciclastic sedimentary rocks of the Lusitanian Basin and, along the basin edge, Precambrian to Paleozoic metamorphic rocks of the Iberian Variscan Massif (Figs. 1 and 2A). This cover is relatively thin, though the thickness increases in restricted areas that are structurally bounded, where it can reach $70 \mathrm{~m}$. An overall prograding pattern has been recognized in the Pliocene to Pleistocene succession of the western Portuguese Coastal Margin (Reis et al., 1992; Cunha et al., 1993; Soares, 1999; Dinis, 2004). This sequence may be subdivided into an indeterminate number of stacked higher order sequences. As a general rule, these minor sequences have a relatively thin or absent transgressive portion and a thicker regressive portion.

The record is divided into four stratigraphic units (Figs. 2C and 3). Unit 1 is dominated by inner shelf transgressive deposits. Unit 2A unconformably overlies Unit 1 or pre-Cainozoic basement. It consists mainly of fluvio-deltaic coarse sands and gravelly sands. Unit $2 \mathrm{~B}$ overlies Unit 2A or Unit 1 and consists of a coarseningupward sequence that represents an upward evolution from lagoon to alluvial sedimentation. Unit 3 is formed by coarse alluvial sediments that unconformably overlie the previous units and/or the basement. There are limited chronostratigraphic data for the studied deposits. The lower transgressive deposits of Unit 1 are considered equivalent to the Upper Zanclian to Lower Piacenzian (lower to mid-Pliocene) fossil-rich beds found in southern locations of the western Portuguese coastal margin (Silva, 2001). The palynological data from a lignite bed in Unit 2B suggests a Piacenzian age (Diniz, 1984).

Two different morphostructural zones with different sedimentary successions are observed (Fig. 2B). The area west of the River Certima is a relatively uplifted area and, in general, shows a regional tilt to the west or
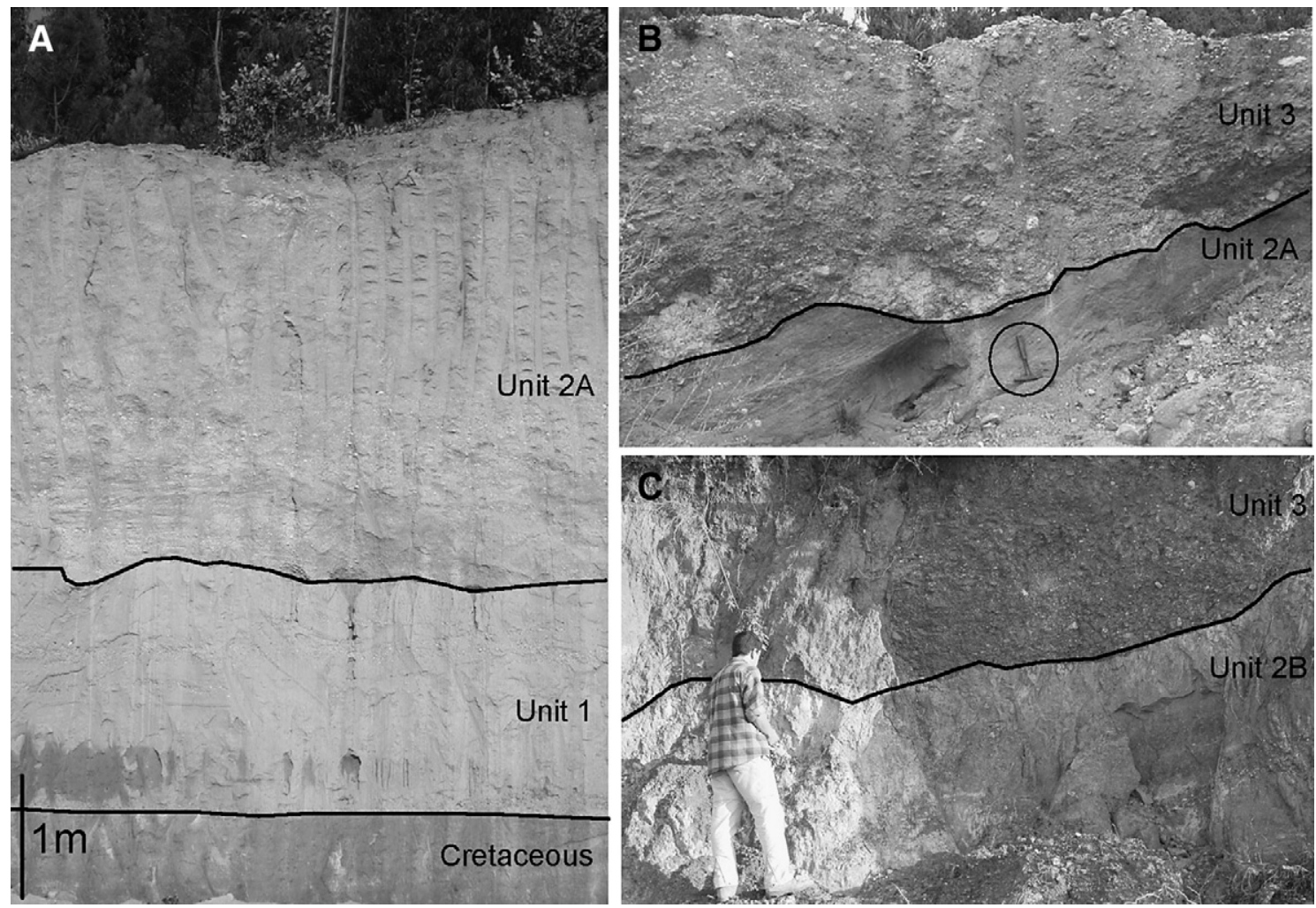

Fig. 3. Broad view of units and facies. (A) Unit 1 between Cretaceous basement sedimentary rocks and Unit 2A; Unit 1 consists of Facies FA, with interbedded, horizontally laminated fine sands and thin beds of coarse sands or gravelly sands; Unit 2A consists of Facies FD, with amalgamated concave-up bodies defining a fining-upward succession. (B) Unit 3 over Unit 2A (hammer for scale); unit 3 with Facies FF2 and Unit 2A with Facies FC, characterized by high angle foreset structures dipping NW. (C) Unit 3 over Unit 2B; Unit 3 with Facies FF2 and Unit 2B with intercalation of Facies FE and FF1. 
northwest. In this area the Neogene cover is thin $(<10 \mathrm{~m})$ and generally comprises merely moderately to well-rounded sand and gravel. The area east of the River Certima is an actively subsiding area where several isolated, small subsiding grabens are separated by narrow horsts. Here the Neogene deposits' thickness varies significantly laterally and reaches the maximum values. Thick mud bodies related to the alluvial infilling of small isolated basins are characteristic of this zone.

The rocks in the hinterland encompass Cretaceous to Cainozoic alluvial units that cover Precambrian and
Paleozoic slates and greywacke, locally affected by high temperature metamorphism, and granitoids (Fig. 1). These rocks contain mainly andalusite, tourmaline, apatite, staurolite and sillimanite in the HM fraction (Soen, 1958; Teixeira et al., 1961; Godinho, 1980). The Variscan Iberian Massif polymetamorphic rocks in the vicinity of the basin also contain garnet and kyanite in the heavy fraction (Potró, 1995; Chaminé, 2000). Of the Lusitanian Basin Mesozoic deposits only the HM assemblages of Cretaceous units have been studied (Soares, 1966). These sediments are dominated by tourmaline, zircon and andalusite (Soares, 1966).

Table 1

Facies characteristics

\begin{tabular}{|c|c|}
\hline Facies & Texture and composition \\
\hline A & $\begin{array}{l}\text { Metre thick fine-grained sand and some decimetre thick } \\
\text { sandy gravel or gravel. Sediments with a mixture of a } \\
\text { dominant well-sorted sand population (mode around } 3 \varnothing \text { ) } \\
\text { and a poorly sorted mud population. Coarser levels with } \\
\text { coarse sand and gravel well-rounded elements. }\end{array}$ \\
\hline B1 & $\begin{array}{l}\text { Intercalations of mature fine to medium sand (mode around } \\
2 \varnothing \text { ), in metre-scale beds, and decimetre thick coarser beds } \\
\text { made of a grain-size varied gravel population and a well- } \\
\text { sorted sand population. Beds of well-sorted medium sand. }\end{array}$ \\
\hline B2 & $\begin{array}{l}\text { Sub-mature medium to coarse sands and gravely sands; } \\
\text { grain-size modes between }-1 \text { and } 2 \varnothing \text {; low silt and clay } \\
\text { content }(<10 \%) \text {; well-rounded gravel elements disperse or } \\
\text { as thin intercalations. Sometimes with coarse-grained } \\
\text { gravel beds at the base. }\end{array}$ \\
\hline
\end{tabular}
gravel beds at the base.

C Sub-mature coarse sands and gravels; sand sediments with disperse well-rounded to angular gravel elements.

D Poorly sorted angular to well-rounded sands and gravels; the sediment beds may have a decimetre thick gravel lag at the bottom.

E Clayey and sandy grey mudstone with thin levels (up to $5 \mathrm{~cm}$ ) of mature fine sand; Thick (up to $5 \mathrm{~m}$ ) red, purple or grey mudstones; immature sandy mudstones with mica rich sand intercalations; Metre-scale lignite beds.

F1 Metre thick very immature, mud-supported or clastsupported gravels (granule to pebble) with frequent slate clasts; mica rich immature sands.

F2 Metre thick immature clast supported gravels (pebble to cobble) with decimetre thick sandy intercalations.

Geometry
Tabular, laterally
persistent. Up to $2 \mathrm{~m}$
thick.
Tabular or convex up
longshore oriented
bodies. Usually less
than $1 \mathrm{~m}$ thick, but
can reach 5 m.
North-south oriented
ribbons.
Under and westward
of thick mud sediments.
Up to 5 m thick.

Lobes or wedges.

Sometimes amalgamated. Up to $3 \mathrm{~m}$ thick.

Concave upward channel packages. $0.5-2 \mathrm{~m}$ thick.

Sheets, lenses or lobes. Up to $10 \mathrm{~m}$ thick.

Lobes and lenses. $0.5-1 \mathrm{~m}$ thick.

Thick sheets up to $3 \mathrm{~m}$.

$\begin{array}{ll}\text { Structures and paleocurrents } & \text { Environment } \\ \text { Massive, horizontally } & \text { Inner shelf } \\ \text { laminated or ripple } & \\ \text { laminated; coarse } & \\ \text { sediments may show large } & \\ \text { scale oscillation ripples. } & \end{array}$
Swaley, planar or trough cross-stratification;

Shoreface and beach polymodal paleocurrents. Low angle or parallel lamination.

Oblique cross-stratified beds (decimetre to a few metre thick) and parallel laminated beds. Frequent bipolar or polymodal paleocurrents; onshore (E) and longshore $(\mathrm{N}-\mathrm{S})$ directed paleocurrents are common.

Cases of Gilbert type profile. Frequently with unidirectional basin ward paleocurrent. Soft sediment deformation.

Massive or crossstratification. Imbrication.

Massive, ripple lamination, parallel lamination or lenticular bedding. Macropeds, concretions and mottles. Massive or crudely stratified. West directed paleocurrents

Massive, crude stratification and imbrication in coarse grained sediments. West or northwest directed paleocurrents
Dune and bar in coastal submarine and estuarine settings

Foreset accretion facies in prograding coasts Fluvial channel

Coastal lagoon; shallow lakes; floodplain and distal alluvial fan

Debris flow dominated alluvial deposits Mixed water lain and debris-flow alluvial deposits 


\section{Methodology}

Eight facies were defined in the cover succession (Table 1). These facies are interpreted as the product of diverse sedimentary environments, from inner marine shelf to coarse alluvial fans. In this paper we consider HM assemblages in the context of this facies framework. Samples were collected from selected sections allowing, as far as possible, an even distributionalong the study area (Fig. 2). The selection of samples also focused on a satisfactory coverage of the diverse facies and stratigraphic units. Poor outcrops, where facies identification is hard to establish, were rejected.
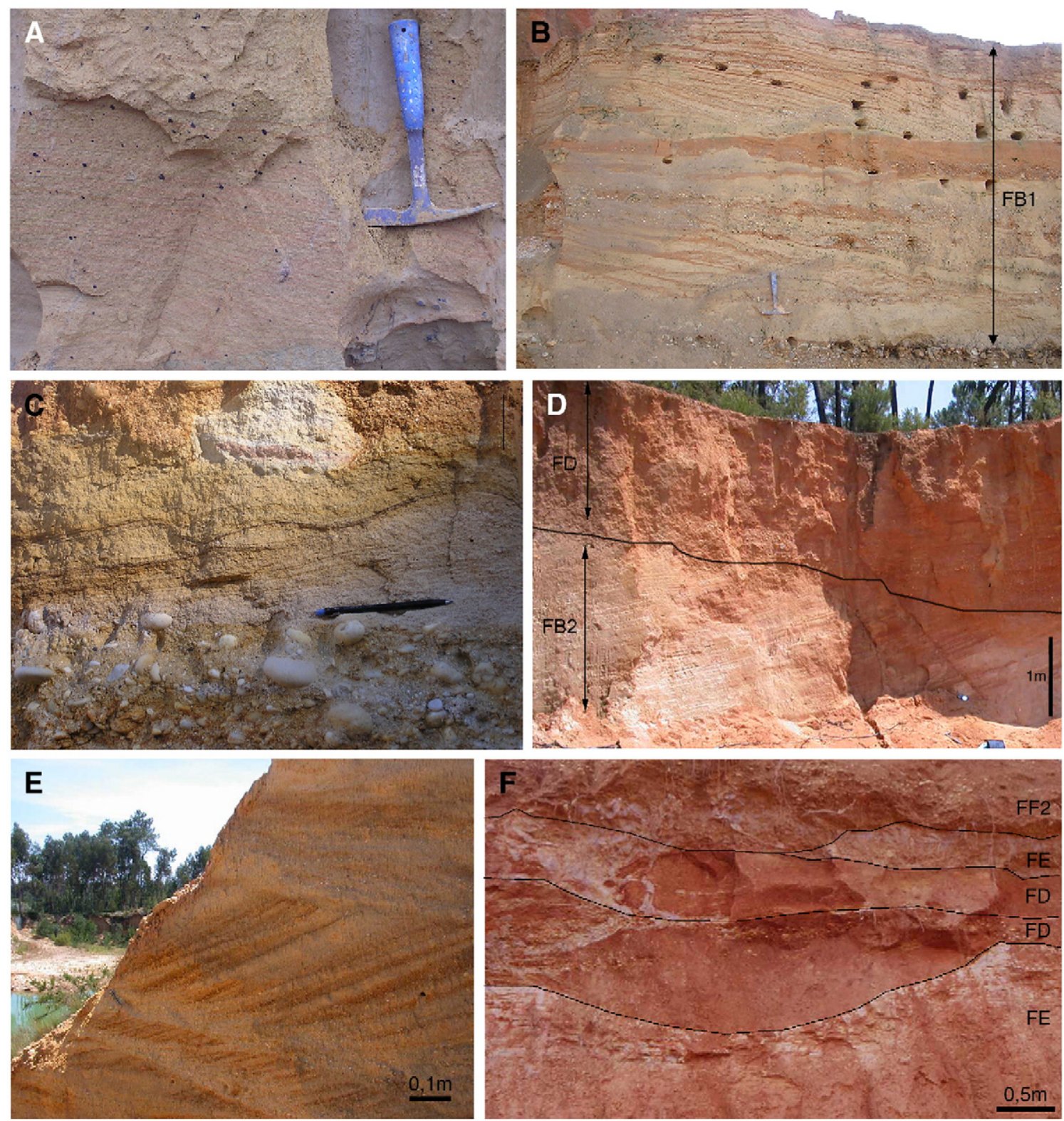

Fig. 4. Photographs of facies. (A) Facies FA comprising horizontally laminated, well-sorted, very fine sand. (B) Facies FB1 over a dm thick gravel bed interpreted as a transgressive ravinement lag; here FB1 is characterized by cross-stratified fine sands interbedded with gravelly sands. (C) Detail of swaley cross-stratified sandy facies FB1 over a transgressive ravinement lag. (D) At least $2 \mathrm{~m}$ thick cross-stratified sand bed (facies FB2) covered by fining-upward gravelly sand to coarse sand channel-fill body (facies FD). (E) Facies FB2 with intercalations of cross-stratified and parallel laminated coarse sands; the paleocurrents in cross-stratified beds are directed towards the southeast. (F) Well defined concave-up base of massive channel bodies (Facies FD) enclosed in mottled mud sediments (Facies FE); these sediments are overlain by coarse alluvial facies (FF2). 
Grain-size was determined by sieving in a column with $1 / 4 \varnothing$ increment. HM composition was determined in 101 samples. For each sample, the HM analysis was performed twice: in the very fine sand $(125-63 \mu \mathrm{m}, 3-4 \varnothing)$ and in medium to fine sand (355-125 $\mu \mathrm{m}, 1.5-3 \varnothing)$ fractions. The samples were cleaned with $50 \%$ dilute $\mathrm{HCl}$ to facilitate mineral identification. The reason for this treatment is the presence of $\mathrm{Fe}-\mathrm{Mn}$ and clay coatings that are not necessarily removed with Na-dithionite treatment. Separation was obtained by the gravitational method using tetrabromethane liquid $(d=2.875)$. The grains were mounted on a glass slide with Canada Balsam. Mineralogy was determined using a petrographic microscope based on physical and optical properties. At least one hundred translucent grains were counted in each slide, using the Ribbon method (Galehouse, 1971). Mica counts were included. The number of opaque grains, counted independently of transparent grains, was noted.

To evaluate the extent of HM alteration by the acid treatment, the mineralogy of a set of non-HCl-treated samples was determined from glass slides. These samples were also analysed by X-ray diffraction in a Philips PW3710 applying the powder method. Since carbonates were not detected and apatite was rarely found in this sample set, the potential bias from using $\mathrm{HCl}$ was considered minimal.

\section{Sedimentary facies}

\subsection{Inner shelf facies (FA)}

\subsubsection{Description}

Facies A (FA) is dominated by metre-thick, very well to well-sorted fine sands (Figs. 3A and 4A). FA is generally structureless but may show parallel lamination (Fig. 4A) or oscillation ripples. Decimetre thick sandy gravel beds with sharp erosional bases are common. These beds contain well-rounded clasts of granule to pebble-size and may be massive, or show clast imbrication or large scale symmetrical ripples. One significant feature of FA is their grain-size homogeneity, marked by a sand modal size always at $2-3.5 \varnothing$ and a silt modal size

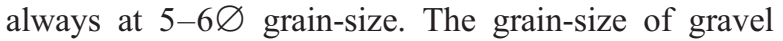
modes are more varied, where gravel is present. Thin mud layers (centimetre-scale) are also locally intercalated in this facies. FA constitutes metre thick tabular sediment bodies several kilometres in lateral extent. They are typically the lowermost Neogene facies. In western and northern, relatively subsiding locations, this facies may be intercalated with other coastal deposits.

\subsubsection{Interpretation}

The well-sorted fine to very fine sands dominated internally by parallel lamination and oscillation ripples, and the tabular geometry, point to inner shelf deposition. The absence of hummocky cross-stratification and the depositional sequence of massive gravelly sands followed by rippled gravelly sands, parallel laminated sands and oscillation rippled sands are indicative of storm influenced coarse-grained deposits (Cheel and Leckie, 1992). The lack of primary sedimentary structures in apparently structureless sands is attributed to pervasive bioturbation.

\subsection{Shoreface and beach facies (FB1)}

\subsubsection{Description}

A complete facies B1 (FB1) succession comprises three distinct deposits. The most common deposits are massive or low angle cross-laminated, fine- to mediumgrained, well-sorted sands. Underlying these beds, FB1 may also be formed by sets of metre-scale cross-stratified medium- to fine-grained sand intercalated with decimetre thick beds of imbricated gravel and crossstratified gravelly sand (Fig. 4B). The paleocurrent direction determined from cross-stratification is typically toward the west or northwest, while the gravelly beds show higher variability in direction (Fig. 5). Locally, swaley cross-stratified fine sands occur in the lower part of an FB1 facies body. In places, the base of this facies is marked by a tabular, decimetre thick gravel bed (Fig. 4B), which is laterally persistent for hundreds of metres, and overlain by a centimetre to decimetre thick mud bed (Fig. 5). FB1 is usually up to $1 \mathrm{~m}$ thick except in low-lying locations where it can reach $3 \mathrm{~m}$. FB1 is locally intercalated with other coastal plain facies.

\subsubsection{Interpretation}

The tabular gravel bed is interpreted as a transgressive ravinement lag. The well-sorted fine sand intercalated with coarse-grained sand and gravel are interpreted as shoreface deposits. Textural and paleocurrent variability must be explained by the constantly changing hydrodynamic conditions observed in the shoreface (Hiroki and Terasaka, 2005). The upper, low angle laminated or massive fine to medium sands are interpreted as foreshore or backshore deposits, respectively. The superposition of shoreface and foreshore/backshore deposits defines a prograding beach sequence. The occurrence of a transgressive ravinement lag at the bottom of this facies suggests that they were deposited following transgressive events. 

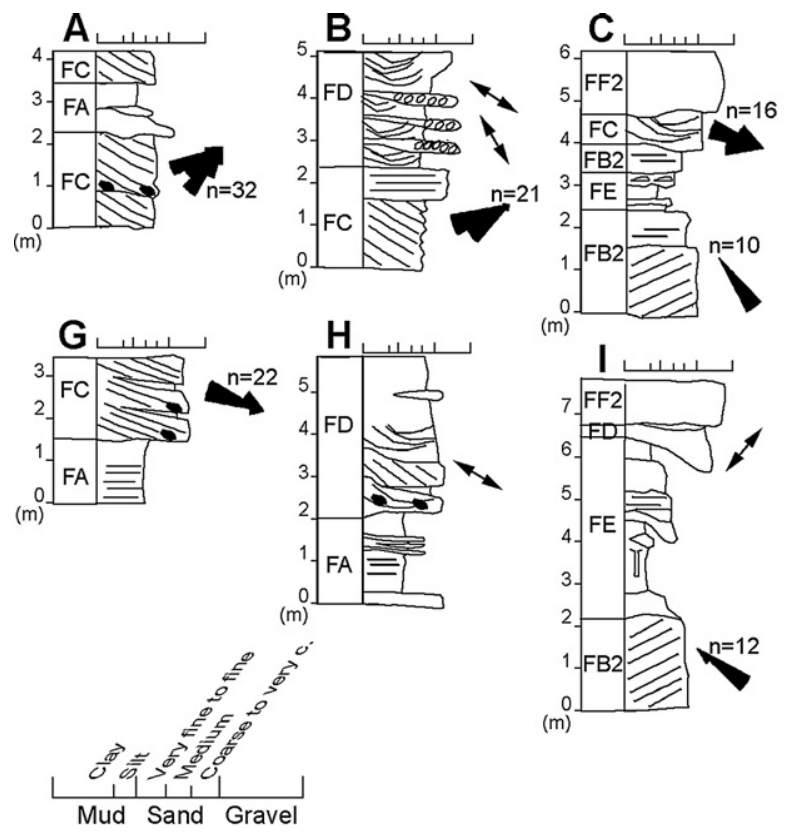

(m)
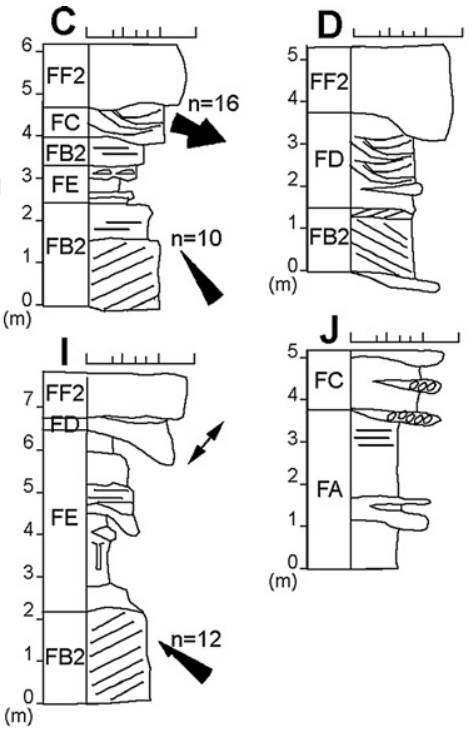

$$
(\mathrm{m})
$$
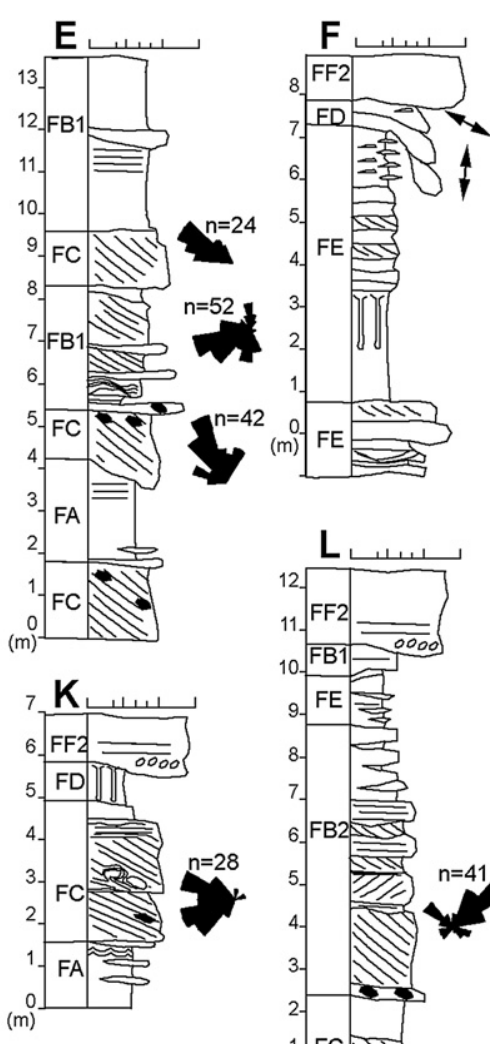
ose diagram

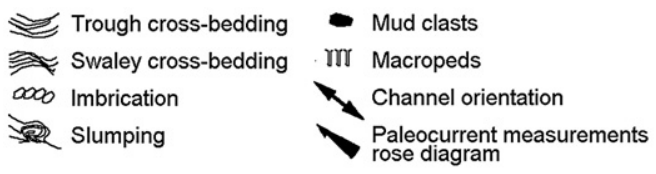

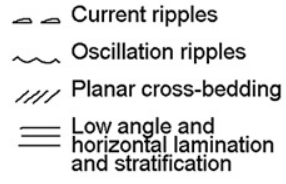

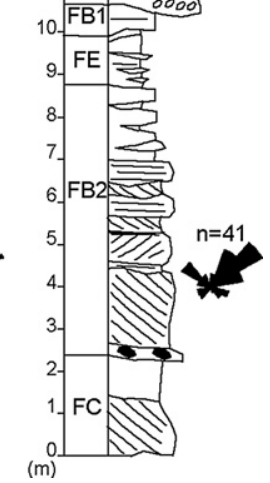

Fig. 5. Representative graphic sedimentary logs (location marked on Fig. 2). Most sections show a regressive facies evolution, with Facies FA or FB at the base of the section that passes upward into Facies FC and FD. In western locations the record has mainly coastal plain (FC, FD and FE) and nearshore facies (FA, FB1 and FB2). These facies are found intercalated at subsiding and more marine influenced locations (sections A and E). Facies FB1 (section E) can show well defined polymodal paleocurrent distributions, although with a dominance of basinward (to the west) orientations. These facies begin with a conglomerate bed (transgressive ravinement lag), followed by fine sands with swaley cross-bedding. Note the domain of southwest to northwest directed paleocurrent directions in Facies FC and the geographic variability, frequently indicating paleocurrents directed onshore (section L) or longshore (sections C and I), in Facies FB2. Facies FC is locally affected by slumping (section K). In eastern subsiding locations the fine-grained Facies FE is thicker (sections F, K and L) and may constitute the majority of the sedimentary record (section F). These finegrained deposits cover sand-dominated coastal plain sediments. Except for the more westerly located sections, the record generally ends with coarse alluvial fan facies (FF2).

\subsection{Coastal bar and dune facies (FB2)}

\subsubsection{Description}

Facies B2 (FB2) consists of cross-stratified, moderately to well-sorted medium- to coarse-grained sand, occasionally with dispersed, well-rounded gravel. The thickness of cross-stratified beds varies between a few decimetres and $2.5 \mathrm{~m}$. The paleocurrents show high directional variability from place to place (Fig. 5). In metrescale beds (Fig. 4D), even though a polymodal paleocurrent distribution may occur, it is frequent to note a predominance of east (onshore) or south (almost longshore) directed paleocurrents. It is also common to find rhythmically interbedded sand bodies with alternating onshore-directed cross-stratification and horizontal lam- ination (Fig. 4E). Well-rounded spherical or disc-shaped, centimetre size gravel dispersed in a sandy matrix or as laterally persistent thin beds and the presence of mud clasts (centimetre to decimetre long axis) are common features. FB2 usually crops out westward of mud-dominated sections and tends to be overlain by them.

\subsubsection{Interpretation}

Deposition in a coastal setting is proposed for FB2 on the basis of geometric features (lateral extent, scarcity of channel forms), textural features (moderate to high textural maturity), paleocurrent distributions (high lateral variability, frequently directed onshore or longshore, and sections with bipolar or polymodal distributions) and location basinward of mud-dominated sediments 
(Nishikawa and Ito, 2000; Anthony et al., 2002). Facies FB resemble in texture and structure the deposits of migrating sandwaves (Allen, 1980; Dalrymple, 1984) and the tidal deltas formed during late transgressive stages in wave-dominated coastal settings (Nishikawa and Ito, 2000).

\subsection{Delta foreset facies (FC)}

\subsubsection{Description}

Cross-stratified, moderately to poor-sorted, very coarse to medium sands with disperse rounded to sub-angular gravel-size clasts are the most common lithology of Facies $\mathrm{C}$ (FC). This facies is dominated by planar metre-scale foreset beds (Fig. 3B) with paleocurrents typically westdirected (Fig. 5). In places, coarse-grained foreset beds dipping 15 to $30^{\circ}$ pass upwards into decimetre thick medium-grained sands with parallel stratification, low angle cross-stratification or backset stratification, defining a Gilbert-type profile. The more common vertical sequences are fining-upward, although coarsening-upward sequences are locally present. FC shows abundant syndepositional deformation, such as small faults, water escape structures and slump folds. The deformation in places marks shifts in paleocurrent direction at outcrop scale. FC locally contains outsized mud balls, with long axis around $0.5 \mathrm{~m}$, aligned parallel to the dip of foreset beds. This facies typically overlies FA unconformably and may be intercalated with FB1 and FB2. In uplifted sectors, $\mathrm{FC}$ directly overlies basement in places.

\subsubsection{Interpretation}

The bed geometry, internal structure and paleocurrent direction of FC are keys to its interpretation and discrimination from coarse-grained FB2. The presence of Gilbert-type profiles and the homogeneity in accretion pattern suggests that FC is related to frontal accretion bars in coarse-grained delta lobes (Orton and Reading, 1993). FC is interpreted to have been deposited during progradational phases imposed by high sediment supply. The high sediment supply conditions may have favoured soft sediment deformation.

\subsection{Coastal plain fluvial channel-fill facies (FD)}

\subsubsection{Description}

Facies D (FD) comprises moderately to poor-sorted, sand and gravel deposits, with lenticular cross-sectional geometry (Fig. 4F). In general the deposits are dominated by angular to sub-rounded clasts, though where FD overlies FA and FB, the clasts tend to be very well rounded. The base of this facies is locally a coarse gravel that passes vertically into sands and gravelly sands. FD geometry in cross-section is characterized by a concaveup basal surface and a planar or concave-up top surface (Fig. 4F). Where several sand and gravel channel bodies stack over each other this geometry is locally obscured. The sediment bodies range from 0.5 to $2 \mathrm{~m}$ thick. An upward transition from gravel and sand to mud-dominated lithology (Facies E) is common. The paleocurrents in western, uplifted, coastal plain sectors are normally to northeast to southeast. In the eastern, subsiding, sectors they tend to be north directed in southern locations and highly variable in northern locations.

\subsubsection{Interpretation}

The concave base geometry, common normal grading and texture indicate that FD are fluvial channel-fill sediments. However, the geometry and texture of these bodies vary according to the geologic setting. In uplifted sectors, successive low sinuosity channel bodies are amalgamated and the mud bodies are rare and thin. This architecture can be explained in terms of accumulation under low accommodation conditions. Cannibalization of nearshore deposits in these locations is likely to explain the presence of well-rounded clasts in FD. In the southern, slightly subsiding sectors, the $\mathrm{N}-\mathrm{S}$ directed channels are oriented parallel to regional structural alignments. In more subsiding sectors the variability in paleocurrent data suggest moderate to high sinuosity channels. In these places FD tends to be found intercalated with mud (Facies E) and contain higher proportion of angular clasts.

\subsection{Distal alluvial fan, floodplain, palustrine and lagoon facies (FE)}

\subsubsection{Description}

Mud-dominated sediments constitute facies E (FE). In places, these facies are formed by grey clayey mudstones with plant debris. At the western border of muddominated sediment bodies, FE is in many places intercalated with FB1 and FB2. FE can also comprise interbedded, texturally sub-mature medium to fine sand and mud with abundant plant fragments. Locally, FE comprises thick, horizontally laminated mud beds (2$10 \mathrm{~m}$ ) with varied colours (grey, red or purple). These deposits may be intercalated with metre thick lignite beds. Heterolithic mud-sand facies with lenticular or wavy bedding is also locally present. Near channel-fill facies (FD) FE may constitute ribbons or lobes in plan view of mostly red mudstones with some immature mica rich sands. The thick mud beds show metre long and a few centimetre diameter macropeds, concretions and mottles (Fig. 4F). As a general rule, FE is more abundant and 
thicker in restricted subsiding sectors, especially upstream of uplifted blocks. They typically cover coarser-grained, coastal plain sediments.

\subsubsection{Interpretation}

The geometrical relations between grey clayey mudstones and mature and immature sand deposits suggest deposition in lagoons of wave influenced settings (Dalrymple et al., 1992; Anthony et al., 2002; Bhattacharya and Giosan, 2003). The thick muds intercalated with lignites are interpreted as deposits of shallow seasonal lakes or ponds. The macropeds and mottles are interpreted as pedogenic features and indicate periodic subaerial exposure. The mostly red muds with sandy laminae are probably related to deposition on a floodplain close to a channel. As the thickness of red or mottled mud bodies gradually decreases eastward, with a concomitant increase in the thickness of coarse-grained, alluvial bodies (Facies F1), and they locally contain floating coarse sand and fine gravel clasts: these sediments may be related to distal deposition on alluvial fans.

\subsection{Proximal debris flow facies (FF1)}

\subsubsection{Description}

Facies F1 (FF1) comprises texturally and compositionally immature, gravels and gravelly sands (Fig. 3C). The gravel framework is dominated by pebble-size clasts of rounded, oblate to angular, metasedimentary clasts and very angular quartz. Matrix-supported textures are most common. The sands mostly have high percentages of slate and mica grains. Grain-size and thickness of beds decreases progressively downcurrent. These coarse-grained immature sediments are intercalated with and wedge out against muds (FE). The scours, channel forms and imbrication primarily indicate west directed paleocurrents. The grain-size and thickness tend to decrease westward. FF1 is almost exclusively preserved in the subsiding areas at the boundary between the uplifted Iberian Variscan Massif and the Lusitanian Basin.

\subsubsection{Interpretation}

The commonly matrix-supported texture, poor sorting, progressive decrease in grain-size basinward and high mud content suggest that this alluvial fan facies is related to debris flow processes. The prevalence of debris flow processes is usual in alluvial fans with high clay content in the drainage area basement rocks (Blair and McPherson, 1994). The paleocurrent data and the predominance of quartz and slate clasts suggest that most of the debris flow deposits were fed from the uplifted Iberian Variscan Massif. Given the limited horizontal extent and the clast angularity, deposition of this facies must have occurred after short travel distance ( 1 to $5 \mathrm{~km}$ ).

\subsection{Mixed debris flow and water lain coarse alluvial facies (FF2)}

\subsubsection{Description}

Facies F2 (FF2) is mostly composed of pebble to cobblesize gravels, which are massive (Fig. 3C), imbricated or

Table 2

Mean heavy mineral content of facies

\begin{tabular}{|c|c|c|c|c|c|c|c|c|c|c|c|c|c|c|}
\hline Facies & Grade & $N$ & $\mathrm{Zr}$ & $\operatorname{Tr}$ & St & And & Rut & Sil & $\mathrm{Ky}$ & $\mathrm{Gr}$ & Mic & Alt & ZTR & $\mathrm{Op}$ \\
\hline \multirow[t]{2}{*}{ FA } & $(1.5-3 \varnothing)$ & 14 & 0.7 & 31.6 & 5.6 & 46.8 & 0.2 & 3.0 & 0.8 & 0 & 3.9 & 7.4 & 32.6 & 19.4 \\
\hline & $(3-4 \varnothing)$ & 14 & 8.7 & 26.1 & 5.5 & 33.4 & 1.6 & 3.9 & 1.9 & 0 & 3.4 & 15.4 & 36.4 & 74.3 \\
\hline \multirow[t]{2}{*}{ FB1 } & $(1.5-3 \varnothing)$ & 29 & 0.1 & 30.8 & 8.5 & 39.3 & 0.2 & 8.8 & 2.7 & 0 & 2.3 & 6.8 & 31.2 & 30.5 \\
\hline & $(3-4 \varnothing)$ & 29 & 13.1 & 28.6 & 9.4 & 28.4 & 1.8 & 3.8 & 1.5 & 0 & 4.1 & 9.2 & 43.5 & 80.1 \\
\hline \multirow[t]{2}{*}{ FB2 } & $(1.5-3 \varnothing)$ & 13 & 0.2 & 32.2 & 8.5 & 44.1 & 0.1 & 3.0 & 1.3 & 0 & 1.6 & 7.7 & 32.5 & 16.6 \\
\hline & $(3-4 \varnothing)$ & 13 & 6.6 & 23.7 & 6.6 & 41.8 & 0.8 & 4.5 & 0.6 & 0 & 3.8 & 11.4 & 31.2 & 46.9 \\
\hline \multirow[t]{2}{*}{$\mathrm{FC}$} & $(1.5-3 \varnothing)$ & 14 & 0.9 & 25.6 & 15.8 & 41.9 & 0.2 & 3.9 & 1.8 & 0 & 1.1 & 8.9 & 26.7 & 19.5 \\
\hline & $(3-4 \varnothing)$ & 14 & 6.2 & 21.6 & 10.1 & 42.8 & 0.6 & 4.4 & 0.6 & 0 & 3.6 & 10.4 & 28.4 & 24.6 \\
\hline \multirow[t]{2}{*}{ FD } & $(1.5-3 \varnothing)$ & 14 & 0.6 & 26.4 & 18.8 & 37.1 & 0.4 & 3.4 & 0.9 & 0 & 2.0 & 10.4 & 27.4 & 27.2 \\
\hline & $(3-4 \varnothing)$ & 14 & 7.1 & 17.8 & 14.0 & 32.2 & 1.8 & 5.9 & 1.5 & 0 & 10.1 & 9.0 & 26.8 & 45.8 \\
\hline \multirow[t]{2}{*}{$\mathrm{FE}$} & $(1.5-3 \varnothing)$ & 7 & 1.7 & 37.3 & 8.6 & 33.0 & 0.3 & 2.7 & 1.9 & 1.4 & 4.6 & 9.9 & 34.4 & 29.4 \\
\hline & $(3-4 \varnothing)$ & 8 & 9.0 & 27.5 & 8.8 & 29.8 & 2.6 & 2.9 & 1.4 & 0.3 & 3.5 & 8.9 & 39.1 & 83.6 \\
\hline \multirow[t]{2}{*}{$\mathrm{FF} 1$} & $(1.5-3 \varnothing)$ & 3 & 0.7 & 25.0 & 4.3 & 51.7 & 0.0 & 3.3 & 2.7 & 0 & 1.3 & 10.0 & 25.8 & 54.0 \\
\hline & $(3-4 \varnothing)$ & 3 & 3.7 & 6.3 & 1.0 & 13.7 & 0.3 & 2.0 & 1.0 & 0 & 66.7 & 5.3 & 40.7 & 10.3 \\
\hline \multirow[t]{2}{*}{ FF2 } & $(1.5-3 \varnothing)$ & 6 & 0.7 & 36.0 & 22.7 & 26.0 & 0.7 & 2.3 & 0.8 & 0 & 3.0 & 8.3 & 37.3 & 42.5 \\
\hline & $(3-4 \varnothing)$ & 6 & 8.3 & 28.8 & 9.0 & 20.7 & 2.0 & 1.8 & 0.3 & 0 & 7.5 & 21.5 & 39.2 & 91.8 \\
\hline
\end{tabular}

N: Number of samples. Zr: Zircon. Tr: Tourmaline. St: Staurolite. And: Andalusite. Rut: Rutile. Sil: Sillimanite. Ky: Kyanite. Gr: Garnet. Mic: Mica. Alt: Alterites. Values as percentage of transparent elements. ZTR: Zircon+ Tourmaline + Rutile/total translucent minerals. Op: Independent number of opaque minerals after counting 100 transparent minerals. 
show crude stratification (Fig. 3B). Some sand and gravel lenses with planar and trough cross-stratification were found intercalated with the more disorganized sediments. Clast composition varies significantly laterally. A wide range of clast roundness and composition can be observed in individual sample sites. FF2 constitutes thick sheets (up to $3 \mathrm{~m}$ ), sometimes with trough forms a few $\mathrm{dm}$ wide and high at the base. This facies is the main constituent of Unit 3.

\subsubsection{Interpretation}

Horizontally coalescent FF2 define alluvial fan bodies whose radius can reach $10 \mathrm{~km}$. The occurrence of both clast-supported and matrix-supported textures, a higher structural organization when compared to FF1, the presence of sheet geometries and the intercalation with channel-fill deposits suggest mixed non-cohesive debris flow and streamflow processes. The diversity of clast composition and roundness is indicative of diverse
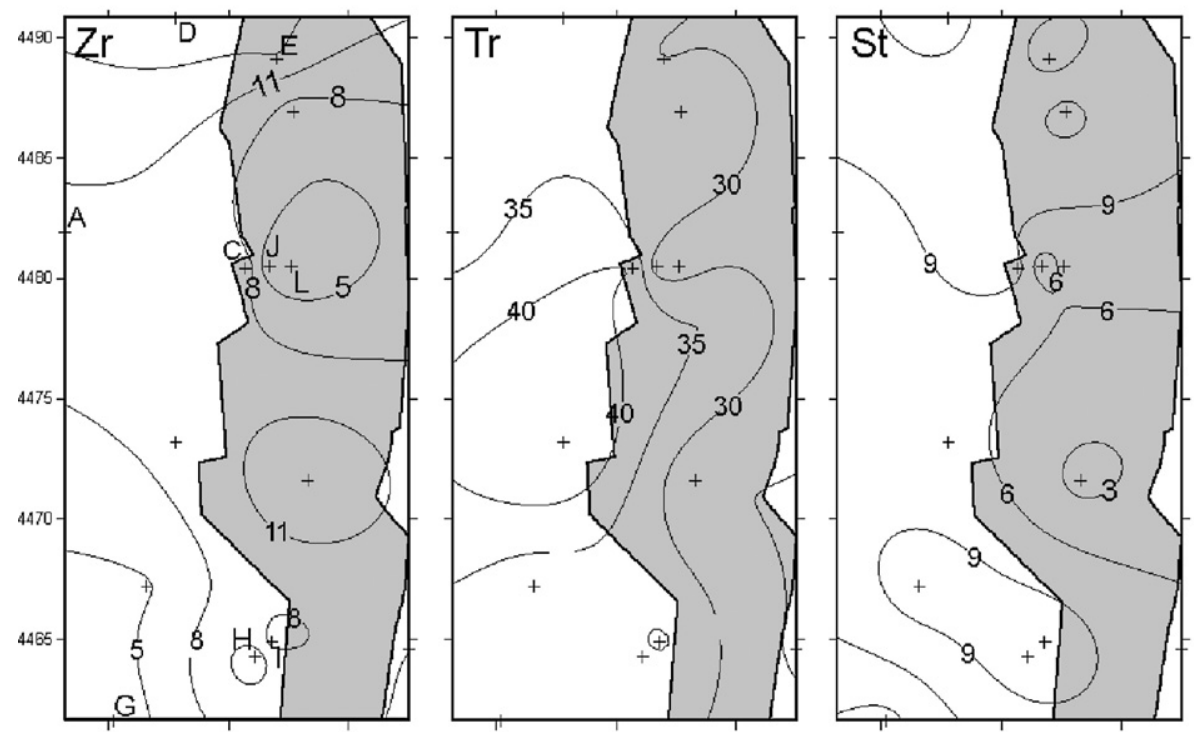

$F A+F B$
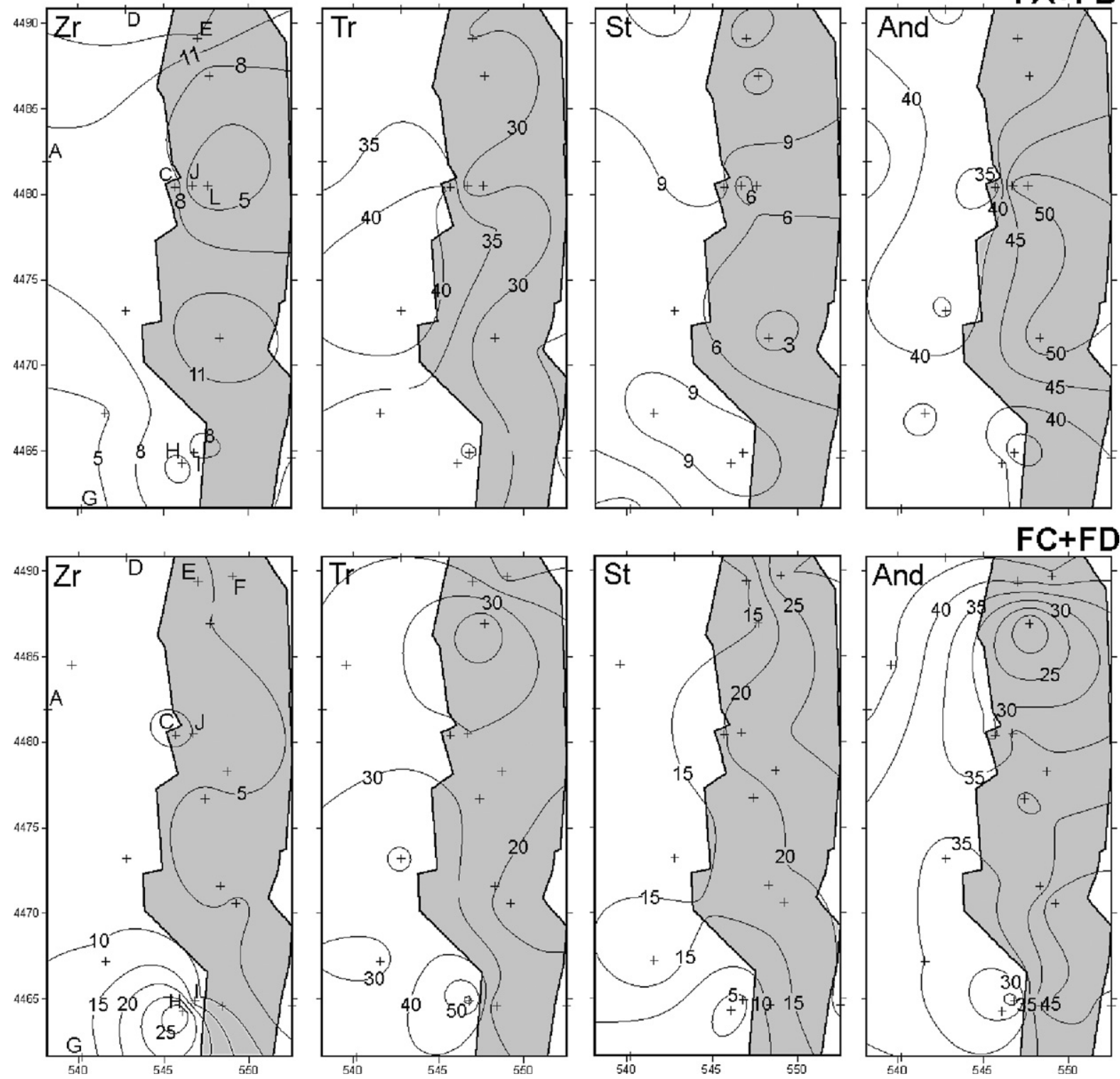

$\mathrm{FC}+\mathrm{FD}$

Fig. 6. Spatial variations in nearshore facies $(\mathrm{FA}+\mathrm{FB})$ and prograding coastal plain facies $(\mathrm{FC}+\mathrm{FD})$. Mineral content as mean percentages of the $\mathrm{HM}$ population along a section in the $3-4 \varnothing$ fraction for zircon $(\mathrm{Zr})$ and in the $1.5-3 \varnothing$ fraction for tourmaline (Tr), staurolite (St) and andalusite (And). Note the gradual westward decrease in staurolite and high percentages of zircon and tourmaline in some southwestern sections of prograding coastal plain facies. Crosses show section locations. Crosses with letters indicate sections illustrated in Figs. 7, 8 and 9. The shaded area represents the overall subsiding coastal margin. 

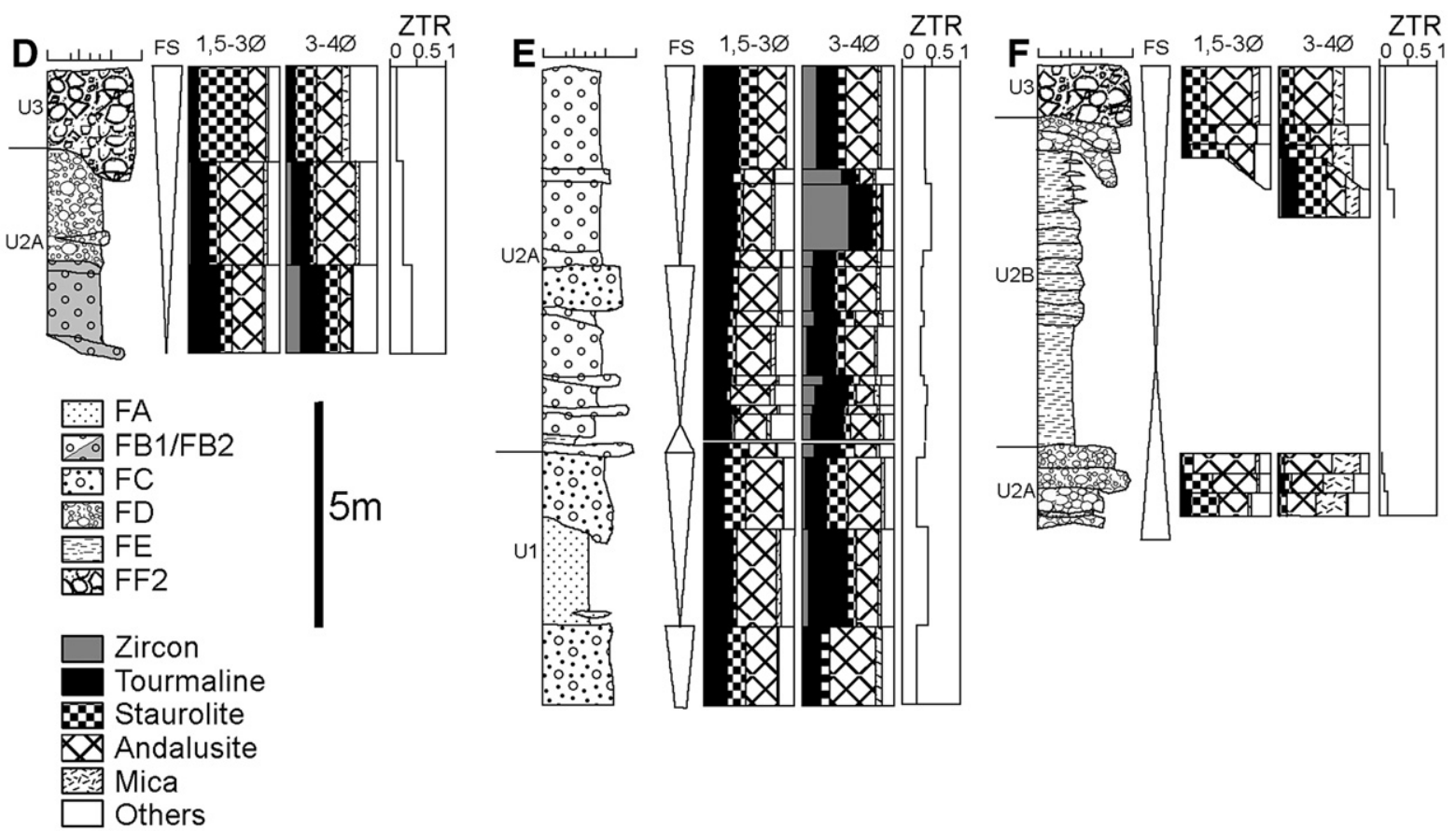

Fig. 7. Vertical variation of heavy mineral composition (see Fig. 2 for location). Selected sections are in more marine-influenced locations. The ultrastable elements are more abundant in more distal facies. FS represents the facies sequences (arrowhead for the more distal facies). ZTR index (summed percentages of zircon, tourmaline and rutile in the transparent HM) for a sediment bed determined from the mineralogical data of the two grain-size fractions weighted by the grain-size frequency and HM concentration at each grain-size fraction. The sedimentary units are indicated on the left side of each section.

provenance. The presence of well-rounded elements suggests reworking of previous deposits, with coeval introduction of rounded nearshore sediments and very angular non-abraded materials from the clay rich Variscan Iberian Massif. The variety in source sediments may explain the non-cohesive character of the processes responsible for these facies. In fact, more dilute processes are expected in deposits whose basement rocks in the drainage area have relatively low clay content (Blair and McPherson, 1994; Nichols and Thompson, 2005).

\subsection{Summary of facies stacking patterns and paleoen- vironmental implications}

As previously mentioned, an overall regressive (prograding) stacking pattern is the most common trend in the studied deposits. However, the detailed architecture in different morphostructural zones is diverse. In general, in the western sections the record is thinner $(<10 \mathrm{~m})$ and constitutes a single sequence, of inner shelf deposits (FA) overlain by coastal plain (FB2, FC and FD) and alluvial fan deposits (FF). Here a sharp unconformity is present at the contact between these deposits and beach sediments (FB1) were not identified between the inner shelf and coastal plain sediments. In places, the coastal plain deposits directly overlie Mesozoic basement rocks. Mud facies are absent or relatively thin in most sections. Conversely, in the eastern sections the thicker record (up to $70 \mathrm{~m}$ ) can comprise several high order sequences. In one section located in the northern reaches of the eastern coastal margin (Fig. 5E) FA, FB1 and FC are found intercalated, defining four high frequency sequences. These sandy coastal sediments are overlain by mud (FE), in places intercalated with channel fill (FD) and coarse alluvial (FF) sediments. In southern locations the record comprises a thick succession (up to $50 \mathrm{~m}$ ) of mud (FE) intercalated with coarse-grained alluvial facies (FF). In sections along the contact with the Marginal Massif, the coarse alluvial facies (FE) are dominant.

The lower thickness, abrupt transition from inner shelf to coastal plain sediments and presence of sharp unconformities between these deposits in western sectors are indicative or very low accommodation space. In opposition, in the eastern sector, the thicker succession, gradual transition between facies and the occurrence of beach deposits intercalated with inner shelf and costal plain deposits are indicative of higher, structurally controlled, accommodation conditions. The north trending paleocurrents in southern reaches of the subsiding area and the transition to more distal facies northward 
suggest an axial drainage system, coincident with the development of the subsiding area. Further, the presence of several high frequency sequences, consisting of coastal plain and shallow marine facies, in the northern reaches of the subsiding region, indicates that it was more marine-influenced than the southern reaches. On the basis of this evidence it is proposed that the differentiation of the western, uplifted, and eastern, subsiding, zones was coeval with the studied deposits. Thus, differences in fault controlled accommodation conditions have probably played an important role on sedimentation and post-depositional evolution.

\section{Heavy mineral (HM) assemblages}

The HM spectrum is somewhat monotonous. The most frequent translucent minerals are andalusite, tourmaline, staurolite, sillimanite, kyanite and mica (Table 2). In the $3-4 \varnothing$ size fraction, zircon is almost always present. Garnet, rutile, anatase and epidote also occur, but generally representing less than $1 \%$ of $\mathrm{HM}$ fraction. Opaque minerals can reach more than $70 \%$ of the heavy fraction, and are generally more abundant in the finer sand fraction $(3-4 \varnothing)$. The X-ray diffraction analyses indicate that goethite and ilmenite are the dominant opaque minerals.

\subsection{Facies $A$}

Facies FA typically yields relatively high amounts of $\mathrm{HM}$ at the very fine sand fraction $(2-15 \%)$. Andalusite (35-58\% of HM grains at $1.5-3 \varnothing ; 20-58 \%$ at $3-4 \varnothing)$ and tourmaline $(23-48 \%$ at $1.5-3 \varnothing ; 14-42 \%$ at $3-4 \varnothing)$ are the dominant minerals. Staurolite in the $1.5-3 \varnothing$ fraction $(2-13 \%)$ and zircon in the $3-4 \varnothing$ fraction (1$23 \%)$ tend to be the most important secondary phases. Mica is common, in both fractions $(0-10 \%)$. The finer fraction tends to have higher quantities of ultrastable minerals than the coarser fraction. Opaque minerals may constitute up to $60 \%$ of the HM assemblage in the very fine sand-size fraction.

\subsection{Facies $B$ (FB1 and FB2)}

The translucent assemblage in facies B (FB1 and FB2) is fairly constant and similar to FA. Nevertheless, two differences deserve mention. FB1 and FB2 tend to have slightly higher proportions of staurolite, sillimanite and kyanite in the $1.5-3 \varnothing$ fraction. In the $3-4 \varnothing$ fraction, the proportions of zircon may be extremely high, in particular in FB1 (2-51\%).

\subsection{Facies $C$}

In both fractions of $\mathrm{FC}$, staurolite (1-35\%) is more abundant than in FA, FB1 and FB2, especially in eastern locations, where it often reaches $30 \%$. The percentages of staurolite in the two fractions are similar. Tourmaline and zircon are less abundant than in FA, FB1 and FB2. Locally, sillimanite is also relatively abundant in this fraction $(<31 \%)$.

\subsection{Facies $D$}

Two populations are recognized in the fluvial channel sediments, especially when the coarser sand
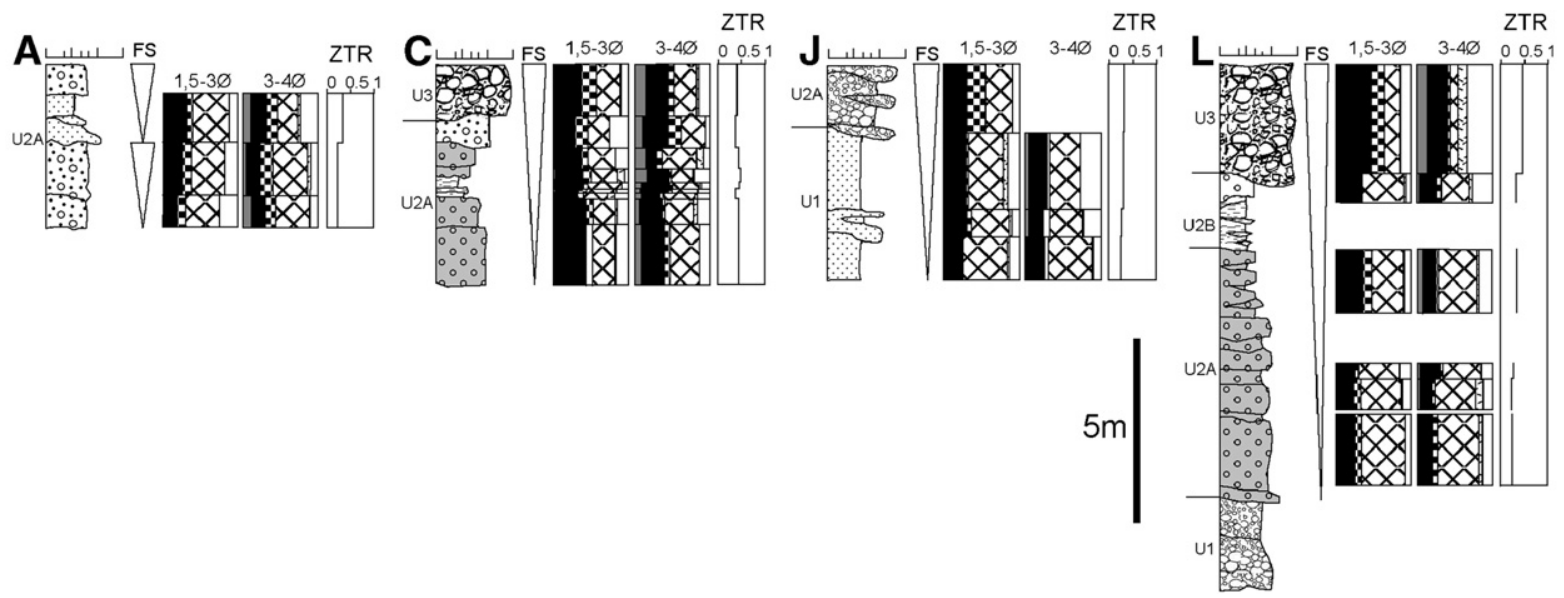

Fig. 8. Vertical variation of heavy mineral composition (see Fig. 2 for location). The sections in more marine-influenced locations show a higher ultrastable mineral content in the more distal facies. Unit 3 coarse alluvial facies may be more abundant in ultrastable minerals than the lower coastal deposits. See Fig. 7 for legend. 
fraction is considered. One population shows a clear dominance of ultrastable minerals, especially tourmaline $(48-67 \%$ in $1.5-3 \varnothing ; 22-52 \%$ in $3-4 \varnothing)$ and zircon (5$36 \%$ in $3-4 \varnothing$ fraction); the other population has a smaller proportion of tourmaline $(1-30 \%$ in $1.5-3 \varnothing$; $1-23 \%$ in $3-4 \varnothing)$ and zircon $(0-10 \%$ in $3-4 \varnothing$ fraction), and a high andalusite $(27-69 \%$ in $1.5-3 \varnothing$; $19-66 \%$ in $3-4 \varnothing)$ and staurolite $(17-43 \%$ in $1.5-3 \varnothing$; $5-32 \%$ in $3-4 \varnothing$ ) content. This population also has higher quantities of opaque minerals in the $3-4 \varnothing$ fraction. The former cluster comprises samples collected from westerly locations, in cases where fluvial channels overlie coastal sediments, while the latter is more common in sections closer to the Variscan Iberian Massif. Here the channel bodies overlie basement rocks or mud facies.

\subsection{Facies $E$}

In the very fine sand-size fraction, both tourmaline $(17-37 \%)$ and andalusite $(14-41 \%)$ are typically the most abundant minerals, while zircon (4-17\%) tends to be the third-ranking mineral. In eastern locations, close to the Variscan Massif, staurolite (0-31\%) and mica (1$15 \%$ ) can be more abundant than zircon.

\subsection{Facies $F$ (FF1 and FF2)}

The HM spectrum in FF varies significantly in vertical and horizontal terms. The $3-4 \varnothing$ fraction of FF2 in the western sector is deprived of mica while FF1 is rich in this mineral $(62-73 \%)$. Besides mica, staurolite and andalusite are the most common minerals in FF1. The spectrum of FF2 is quite heterogeneous, as tourmaline $(12-71 \%)$, andalusite $(13-56 \%)$ and staurolite $(2-53 \%)$ can be the most abundant minerals. The quan- tities of opaque minerals may be exceptionally high in the $3-4 \varnothing$ fraction of this facies $(<75 \%)$. An additional aspect in FF2 is the domain of well-rounded grains in ultrastable assemblages.

\section{Relationships among HM assemblages and facies}

Regarding the spatial variations in the HM assemblage, the prograding coastal plain sediments tend to show a progressive decrease in staurolite westward (Fig. 6). Other possible broad trends in coastal prograding sediments are obscured by the presence of tourmaline and zircon-rich samples in south-western locations (Fig. 6). The nearshore sediments (FA and FB) are more homogeneous, and the horizontal trends are not as consistent as in prograding coastal plain sediments. Sillimanite and kyanite are generally more abundant in eastern locations irrespective of facies. The composition of FE and FF varies strikingly, in both N-S and $\mathrm{E}-\mathrm{W}$ directions. Staurolite is especially abundant in northern sectors west of a present day valley (Águeda river) that extends for tens of $\mathrm{km}$ from the Variscan Iberian Massif (Fig. 7, section D). Tourmaline is more abundant in southern sections (Fig. 8), in particular in the uplifted Costal Margin west of the River Certima (Fig. 9). Mica is especially abundant in the very fine sand-size fraction of alluvial facies close to the Iberian Variscan Massif (Fig. 7).

It is possible to trace trends of HM change that may be related to vertical facies evolution. Where a section has diverse interbedded coastal facies the more distal facies, FA, FB1 and FB2, tend to have a higher ultrastable mineral content than the more proximal facies, FC and FD (Figs. 7 and 8). Where the ravinement lag at the bottom of the transgressive portion of a sequence is
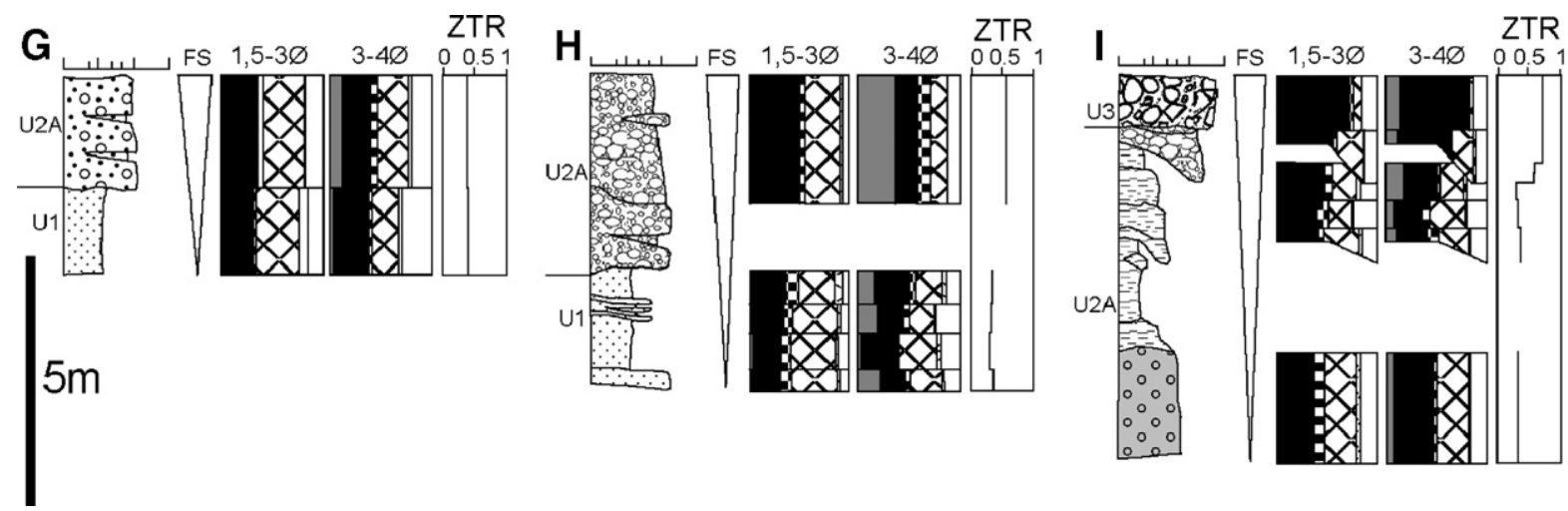

Fig. 9. Vertical variation of heavy mineral composition (see Fig. 2 for location). Sections located in western uplifted coastal margin. There is a tendency for vertical increase in the percentages of ultrastable elements, though less pronounced in western sections. See Fig. 7 for legend. 

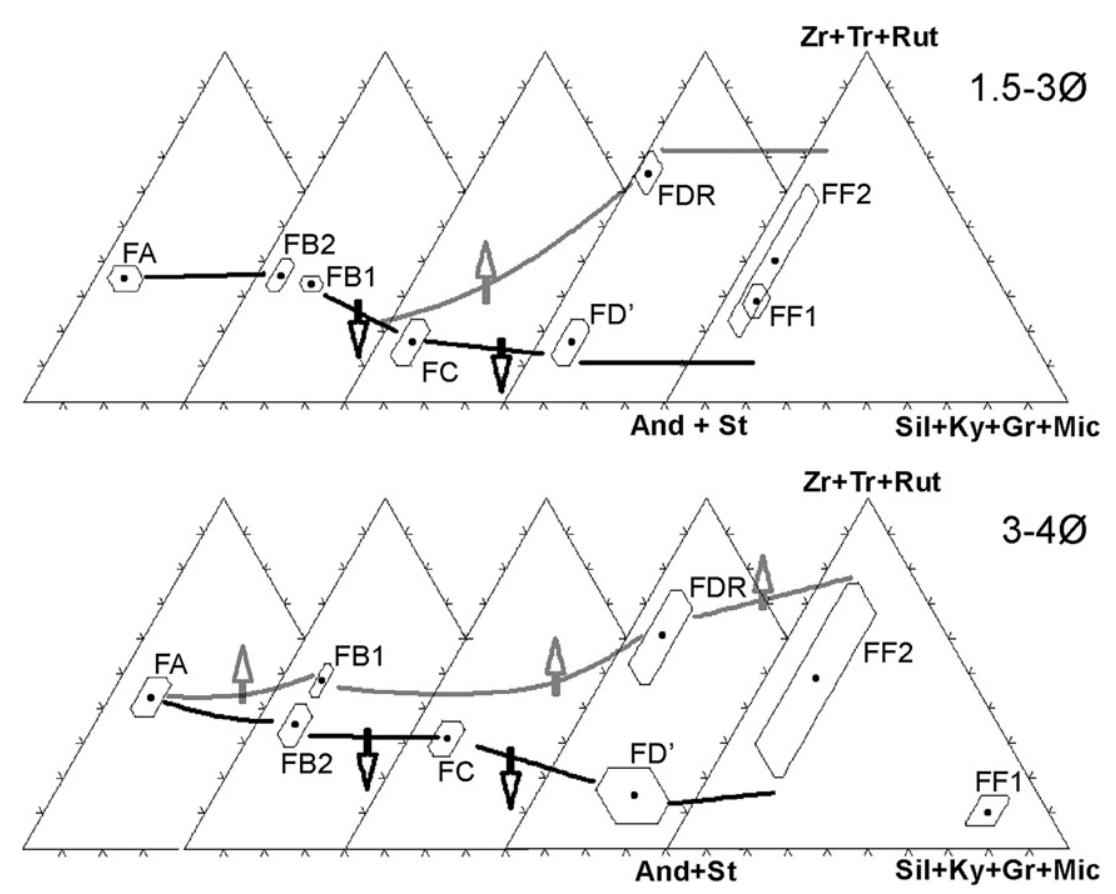

Fig. 10. Mean composition of facies with confidence limits of population means (95\% confidence limit). The successive triangles (left to right) represent the regressive facies stacking (FA to FF). Zircon ( $\mathrm{Zr}$ ), tourmaline (Tr) and rutile are the most frequent ultrastable elements. Andalusite (And) and staurolite (St) are ubiquitous less stable elements derived from the polymetamorphic Variscan Iberian Massif. Sillimanite (Sil), kyanite (Ky), garnet (Gr) and mica (Mic) are less frequent, less stable elements. D' corresponds to FD cluster with a high proportion of stable elements and FD-D' to the other samples. Black arrows and lines represent a trend related to increased input from hinterland areas leading to a decrease in the percentage of ultrastable elements. Grey arrows and lines represent a trend related to alluvial storage, recycling and hydraulic fractionation leading to an increase in the percentage of ultrastable elements accompanying the regressive facies trend. The wide variety in FF1 and FF2 composition is justified by mixed provenance (hinterland, basin margin and recycled). Mica is the main constituent in $3-4 \varnothing$ fraction of FF1.

present, it shows a higher percentage of ultrastable minerals than the underlying, more proximal deposits (Fig. 7). The maximum flooding zone, marked by FA, FB1 or FB2, also tends to have higher concentrations of ultrastable minerals (Figs. 7 and 8). In these sections, FC and FD show higher proportions of staurolite. Conversely, where alluvial deposits (FD and FF) unconformably overlie older coastal sediments, the HM spectrum of those sediments may be very rich in ultrastable minerals (Figs. 8 and 9). This situation is common in uplifted western locations and where Unit 3 overlies nearshore or coastal plain deposits.

Thus, despite the lateral variations in the HM content, there are two opposite trends of HM assemblage change linked to prograding facies stacking patterns. One is characterized by a decrease in the percentage of ultrastable elements and is more common in the more marine-influenced portion of the succession. The other is characterized by an increase in ultrastable species and is more common in the more proximal and younger portion of the succession. These two trends are illustrated in Fig. 10.

\section{Discussion}

\subsection{Hydraulic selection}

Several properties such as density, shape and grainsize in the parent rocks influence the HM signal of sediments by hydraulic segregation (Parfenoff et al., 1970; Mange and Maurer, 1992; Morton and Hallsworth, 1999). Zircon and rutile are the densest of the observed minerals and are more abundant in the very fine sand fraction. The segregation of these minerals in the fine sand fraction would necessarily affect the percentages of the remaining elements and introduce differences between grain-sizes.

The content of zircon, tourmaline, staurolite, andalusite and sillimanite in the two fractions of alluvial deposits (FD and FF) may be correlated (Table 3). This suggests that hydraulic fractionation is limited in these environments and the assemblages are more determined by provenance. Contrastingly, the occurrence of a limited number of significant correlation coefficients in the nearshore facies (Table 3) may be explained by 
hydraulic selection. Several authors have demonstrated that the hydraulic segregation of HM occurs mainly in coastal environments (Swift et al., 1971; Komar and Wang, 1984; Peterson et al., 1986). As stated by Morton and Hallsworth (1999), in beach sands, longer transport allows hydraulic equilibrium to be attained with the lighter minerals and a good correlation may be found between the HM density and HM grain-size. Under these conditions there would be a tendency for some HM segregation by density between the various grainsize fractions.

Since the HM are concentrated in finer size fractions than a sand-size mode of bulk sediment (Fig. 11A), they were probably hydraulically segregated from the lighter sediments by density. To test the hypothesis of hydraulic fractionation of the HM between fractions, the percentages of zircon in the $3-4 \varnothing$ and tourmaline in the 1.5-3Ø were compared in all facies where these minerals did not show valid correlations between fractions (Fig. 11B). These two minerals were selected because they have contrasting density and comparable mechanical and chemical stability. The observed scattering indicates that other factors, beside hydraulic segregation, controlled the HM assemblages. The relation between zircon and tourmaline is also compared in a single section (section E of Figs. 5 and 7), where 22 FB1 samples were collected (Fig. 11C). Though the correlation between the two minerals is not statistically valid, the samples with higher $3-4 \varnothing$ zircon content also tend to be abundant in $1.5-3 \varnothing$ tourmaline. Conversely, higher scattering is found when the content of tourmaline in the two fractions is compared. These dissimilar relationships reinforce the possibility of hydraulic segregation by density between size fractions.

Several authors have demonstrated that hydraulic segregation and concentration of HM in placers is frequent during transgressions (Komar and Wang, 1984; Elsner, 1992). Lower sediment availability during transgression, when compared to progradation, is supposed to favour this segregation. Dillenburg et al. (2004) showed that the fractionation between the heavier and lighter fractions occurs regardless of sea-level changes but is favoured by recycling of previous deposits. In the studied deposits, it seems that, at least occasionally, hydraulic selection may have favoured the enrichment in zircon in the very fine sand fraction of FB1 (Fig. 10).

\subsection{Provenance}

Differences in the composition of the source sediments may explain some of the HM trends. The mineralogical and sedimentological features suggest
Table 3

Mineral content correlation coefficients between fractions $1.5-3 \varnothing$ and $3-4 \varnothing$

\begin{tabular}{llrllrrl}
\hline Facies & Zr & Tr & St & And & \multicolumn{1}{l}{ Mic } & \multicolumn{1}{c}{ Sil } & Gr \\
\hline FA & 0.14 & 0.33 & 0.20 & $\mathbf{0 . 6 8}$ & 0.20 & 0.44 & - \\
FB & 0.10 & 0.03 & $\mathbf{0 . 2 8}$ & $\mathbf{0 . 3 4}$ & 0.06 & -0.18 & - \\
FC & 0.38 & 0.17 & 0.21 & 0.45 & 0.02 & 0.01 & - \\
FD & $\mathbf{0 . 7 2}$ & $\mathbf{0 . 9 2}$ & $\mathbf{0 . 6 8}$ & $\mathbf{0 . 6 3}$ & -0.05 & 0.09 & - \\
FE & 0.04 & -0.41 & 0.03 & 0.41 & 0.50 & -0.23 & $\mathbf{0 . 9 7}$ \\
FF & 0.56 & $\mathbf{0 . 9 3}$ & $\mathbf{0 . 9 4}$ & $\mathbf{0 . 3 3}$ & -0.29 & $\mathbf{0 . 7 5}$ & - \\
\hline
\end{tabular}

Only the most frequent heavy minerals are considered. Mineral explanation in Table 2. Bold values indicate significant correlation coefficient for $95 \%$ probability.

${ }^{\text {a }}$ Significant correlation coefficients when FF1 (0.97) and FF2 (0.86) are considered separately.

three sources: long fluvial systems from hinterland regions that supply mostly tourmaline, andalusite, zircon, staurolite, sillimanite and rutile; short alluvial paths from the border of the Variscan Iberian Massif with pelitic rocks that may supply high quantities of mica; and recycled deposits that tend to be enriched in the most stable elements. Because some of the underlying and hinterland source deposits are related to strong chemical weathering conditions, which originated the kaolinite rich (siderolhitic) and lateritic weathering profiles, their HM assemblages are likely to be poor in unstable elements.

During transgressions, the sediment yield from the hinterland may be reduced due to stream gradient decrease. Leeder et al. (1998) also considered that changes in runoff may lead to lower sediment supply during interglacial, and preferentially higher sea level, periods in Mediterranean-influenced climates. Then, due to relative sediment starvation, higher proportions of the available sediments must result from the reworking of previous coastal margin deposits. Under these circumstances, the HM assemblage tends to be enriched in the most chemically and mechanically stable minerals (Fig. 10). This low-yield-induced recycling is expected in sections in more marine-influenced locations (Fig. 12A and C).

Since the prograding facies were deposited during phases of enhanced supply by relatively long rivers directed from the hinterland and shorter streams from the basin border, it may be argued that the mineral assemblages must have lower proportions of recycled coastal grains. Hence, there may be a trend of ultrastable mineral proportion decrease related to the regressive facies stacking pattern (Fig. 10). The higher proportion of staurolite in eastern locations (Fig. 6) also may be explained by the proximity to the basin edge and to the points of supply from the hinterland (Fig. 12B). 

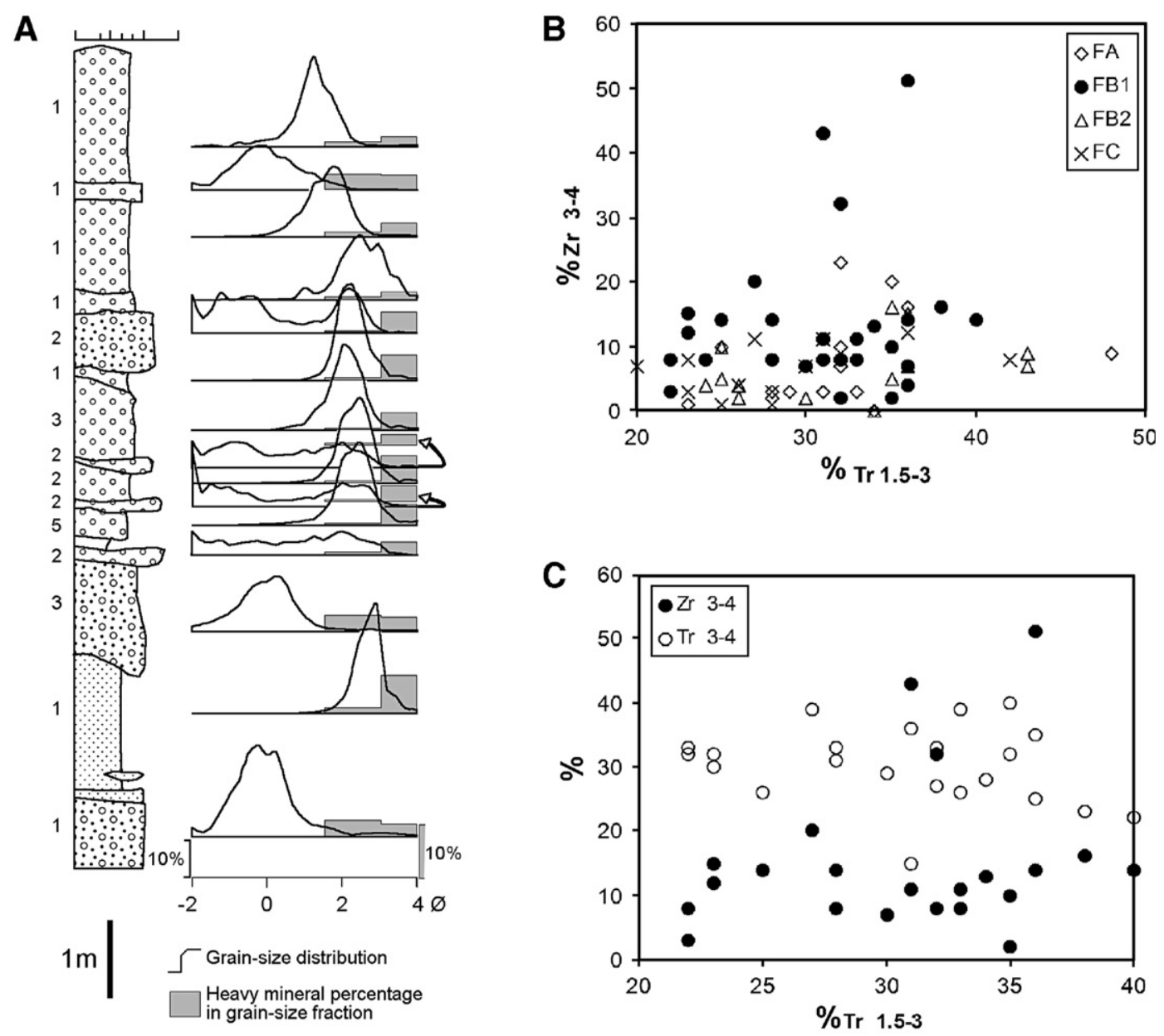

Fig. 11. Relationships between the percentages of contrasting density elements in different size fractions. Bulk grain-size distributions and percentage of HM in the two size fractions along a selected section (A); detailed section description in Fig. 5E and HM composition in Fig. 7; figures at the left of each bed indicate the number of analysed samples. Relationship between the percentages of $1.5-3 \varnothing$ tourmaline and 3-4 $\varnothing$ zircon in FA, FB1, FB2 and FC (B). Relationship between the percentages of $1.5-3 \varnothing$ tourmaline, $3-4 \varnothing$ tourmaline and $3-4 \varnothing$ zircon in FB1 samples from the section represented in A (C).

Meanwhile, the alluvial deposits located close to the basin edge may have had a high mica content fed from the pelitic rocks of the coastal ranges, after short travel (Figs. 10 and 12C).

\subsection{Chemical and mechanical selection}

The lack of carbonates in bulk samples, low garnet content (present in only one section) and complete absence of amphibole, while this mineral is common in present day fluvial, beach and shelf sediments (Pureza and Araújo, 1956; Cascalho, 2000), suggest significant post-depositional removal of some labile phases. However, owing to the acid treatment adopted in this study, it is not possible to evaluate the role of postdepositional sediment weathering.
The occurrence of high tourmaline and zircon proportions may also be explained by mechanical abrasion. Because tourmaline and zircon are mechanically stable minerals (Freise, 1931, in Morton and Hallsworth, 1999; Thiel, 1945), it may be argued that successive reworking episodes would have led to an increase of their proportion due to the breakdown of less resistant elements. However, HM studies have suggested that, in general, mechanical abrasion should play a negligible role on sample assemblages (Morton and Hallsworth, 1999). But sediment recycling with combined mechanical abrasion and chemical weathering during periods of exposure could have led to some alteration of the HM proportions (Fig. 12C). These processes have probably contributed to the formulation of an ultrastable-rich HM assemblage in recycled fluvial channel deposits (FDR 


Facies
$\begin{aligned} & \because \text { FA } \\ & \therefore \text { FB/FC } \\ & \text { FD } \\ & \text { FE } \\ & \text { FE } \\ & \text { FF }\end{aligned}$

A

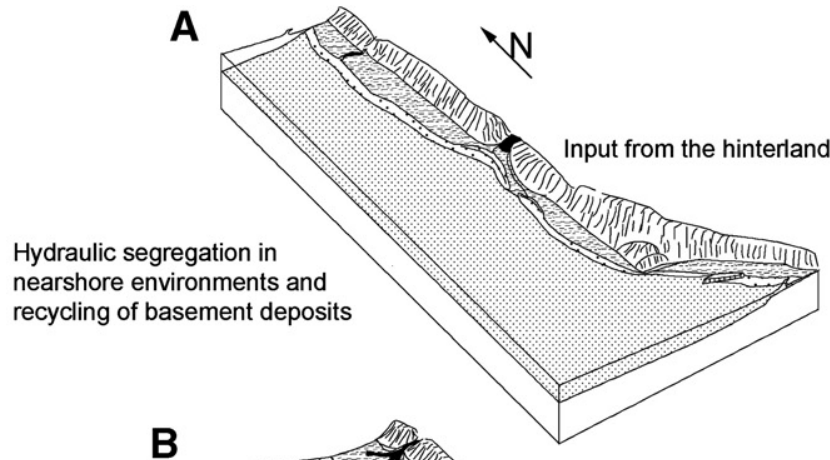

B nearshore environments and recycling of basement deposits

Hydraulic segregation in nearshore environments; recycling of previous sediments is reduced due to the high sediment yield

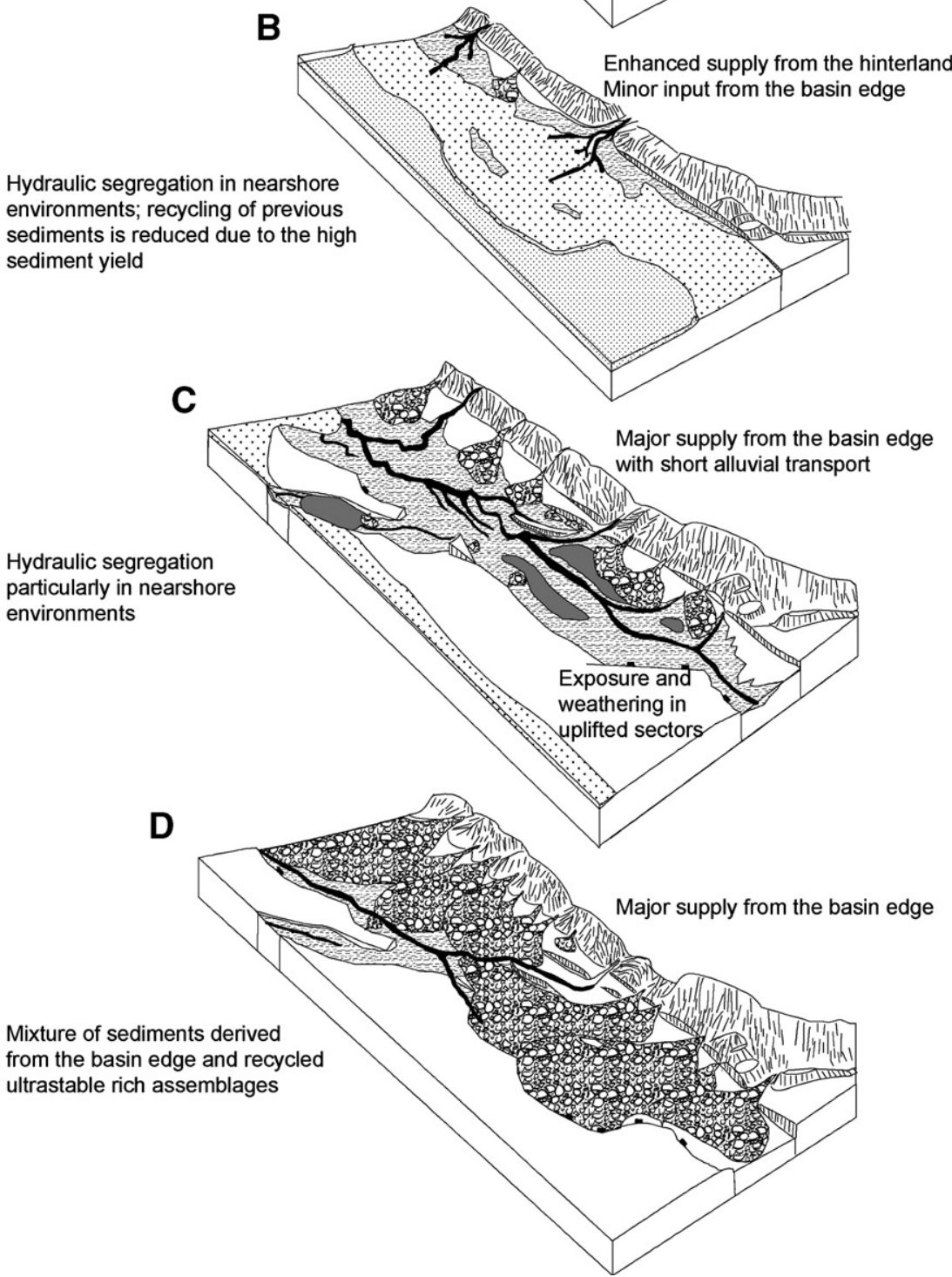

Fig. 12. The four main stages of paleogeographic evolution of the study area and factors that controlled the HM assemblages. Reduced rate of sediment supply during transgressions favoured the recycling of previous deposits (A and C). Hydraulic fractionation and mechanical selection probably contributed to an increase in the proportion of ultrastable elements in nearshore facies (A, B, C). In eastern locations higher proportions of sediments derived from the hinterland are expected (B), and from the coastal ranges (C). The low accommodation conditions in the uplifted and tilted coastal margin west of the River Certima favoured weathering and recycling processes $(\mathrm{C})$. Alluvial facies overlying exposed coastal sediments tend to be enriched in ultrastable elements; in northern, less uplifted areas, and in the east, closer to the Variscan Iberian Massif, the HM spectrum of alluvial facies contains less ultrastable elements (D). 
in Fig. 10). The domain of well-rounded tourmaline in FF2 ultrastable assemblages reinforces the hypothesis of mechanical selection. Hence, selective removal of less stable species due to alluvial storage and recycling of previous deposits may explain the trend of enrichment in ultrastable elements in younger alluvial deposits (Fig. 10). It must have been more active after the uplift and exposure of some sectors of the coastal margin (Fig. 12C).

\section{Conclusions}

The sedimentary record of the study area comprises several minor sequences of transgressive deposits followed by highstand and regressive deposits which are stacked in an overall prograding sequence. The record is in most places a thin and highly permeable sediment blanket, preserved in a low relief area and related to the recycling of previous deposits, part of them of "siderolithic" character. Thus, some minerals that are unstable on weathering, which are usually related to transgressive and maximum flooding surfaces and whose content can be used to trace sequence stratigraphy elements, may be absent. However, it is still possible to find two opposite trends of stable and ultrastable HM assemblage change linked to facies transitions.

The first trend is typical of the older sediments. It is represented by a diminution in the percentages of ultrastable elements associated with regressive facies stacking and an increase associated with transgressive facies stacking. Differences in the composition of the source sediments partially explain this trend. During progradation, the basin received sediments with high andalusite, tourmaline and staurolite quantities brought from hinterland areas in a mixture with other minerals. During transgressions the amount of sediment that arrived from hinterland areas was reduced. A significant component of the available sediment was then probably recycled and would tend to be enriched in ultrastable elements. The nearshore mechanical selection must have also contributed to the increase in proportion of ultrastable minerals. Hydraulic segregation favoured the concentration of zircon and rutile in the very fine sand-size fraction.

The second trend is typical of younger sediments, deposited when environments were displaced basinward, and is more pronounced in uplifted sectors. This trend is characterized by the occurrence of a higher percentage of ultrastable minerals in the younger alluvial facies than in the older coastal deposits. It can be explained by alluvial storage and cannibalization of coastal sediments. The effect of these processes was enhanced in low accommo- dation areas where sediment accumulation was slow, thus leaving sediment available for recycling and weathering processes for longer periods of time.

\section{Acknowledgments}

This work is a contribution of project POCI/CTE60750/2004, financed by the Portuguese Foundation of Science and Technology (FCT). The authors acknowledge H.G. Dill, N. Pimentel, A.C. Morton and editor C. Fielding for their insightful and constructive reviews that greatly improved the clearness and the ideas expressed in the manuscript. An earlier version of this work benefited from critical reviews of $\mathrm{C}$. Bristow and J. Cascalho. P. Cunha is thanked for the valuable comments and discussion on the sedimentology and stratigraphy of Portuguese coeval sediments.

\section{References}

Allen, J.R., 1980. Sandwaves: a model of origin and internal structure. Sediment. Geol. 26, 281-328.

Anthony, E.J., Oyédé, L.M., Lang, J., 2002. Sedimentation in a fluvially infilling, barrier-bound estuary on a wave-dominated, microtidal coast: the Ouémé River estuary, Benin, west Africa. Sedimentology 49, 1095-1112.

Bhattacharya, J.P., Giosan, L., 2003. Wave-influenced deltas: geomorphological implications for facies reconstruction. Sedimentology 50, 187-210.

Blair, T.C., McPherson, J.G., 1994. Alluvial fans and their natural distinction from rivers based on morphology, hydrologic processes, sedimentary processes and facies assemblages. J. Sediment. Res., Sect. A Sediment. Pet. Proc.f 64, 450-489.

Carver, R.E., Kaplan, D.M., 1976. Distribution of hornblend on the atlantic continental shelf off Georgia. Mar. Geol. 20, 335-343.

Cascalho, J.P., 2000. Mineralogia dos sedimentos arenosos da margem continental setentrional portuguesa. Ph.D. Thesis, University of Lisbon, Portugal.

Chaminé, H.I., 2000. Estratigrafia e estrutura da faixa metamórfica de Espinho-Albergaria-a-Velha (Zona de Ossa-Morena): implicações geodinâmicas. Ph.D. Thesis, University of Oporto, Portugal.

Cheel, R.J., Leckie, D.A., 1992. Coarse-grained storm beds of the upper Cretaceous Chungo Member (Wapiabi Formation), Southern Alberta, Canada. J. Sediment. Petrol. 62, 933-945.

Cunha, P.M., Barbosa, B.P., Reis, R.P., 1993. Synthesis of the Piacenzian onshore record, between the Aveiro and Setúbal parallels (Western Portuguese margin). Ciênc. Terra 12, 35-43.

Dalrymple, R.W., 1984. Morphology and internal structure of sandwaves in the Bay of Fundy. Sedimentology 31, 365-382.

Dalrymple, R.W., Zaitlin, B.A, Boyd, R., 1992. Estuarine facies models: conceptual basis and stratigraphic implications. J. Sediment. Petrol. $62,1130-1146$.

Dill, H.G., 1998. A review of heavy minerals in clastic sediments with case studies from the alluvial-fan through the nearshore marine environments. Earth-Sci. Rev. 45, 103-132.

Dillenburg, S.R, Tomazelli, L.J., Barboza, E.G., 2004. Barrier evolution and placer formation at Bujuru southern Brazil. Mar. Geol. 203, 43-56. 
Dinis, P.A., 2004. Evolução pliocénica e quaternária do vale do Cértima. PhD thesis, University of Coimbra. PhD thesis, University of Coimbra, Portugal.

Diniz, F., 1984. Apports de la palynologie a la connaissance du Pliocène Portugais. Rio Maior: un bassin de référence pour le histoire de la flore, de la végétation et du climat de la façade atlantique de l'Europe méridionale. $\mathrm{PhD}$ thesis. University of Montpellier, France.

Elsner, H., 1992. Granulometry and mineralogy of some northeastern Florida placers: a consequence of heavy mineral concentration in nearshore bars. Sediment. Geol. 76, 233-255.

Freise, F.W., 1931. Untersuchung von Mineralen auf Abnutzbarkeit bei im Wasser. Tschermaks Mineral. Petrog. Mitt. 41, 1-7.

Friss, H., 1978. Heavy mineral variability in Miocene marine sediments in Denmark: a combined effect of weathering and reworking. Sediment. Geol. 21, 169-188.

Galehouse, J.S., 1971. Point counting. In: Carver, R.E. (Ed.), Procedures in Sedimentary Petrology. Wiley-Interscience, New York, pp. 385-407.

Godinho, M.M., 1980. O plutonito do Caramulo. Mem. Not., Publ. Mus. Lab. Mineral. Geol. Univ. Coimbra 89-90, 1-269.

Hiroki, Y., Terasaka, T., 2005. Wavy lamination in a mixed sand and gravel foreshore facies of the Pleistocene Hosoya Sandstone, Aichi, Central Japan. Sedimentology 52, 65-75.

Leeder, M.R., Harris, T., Kirkby, J., 1998. Sediment supply and climate change: implications for basin stratigraphy. Basin Res. 10, 7-18.

Komar, P.D., Wang, C., 1984. Processes of selective grain transport and the formation of placers on beachs. J. Geol. 92, 637-655.

Mange, M.A., Maurer, H.F.W., 1992. Heavy Minerals in Colour. Chapman \& Hall, London, U.K.

Morton, A.C., Hallsworth, C.R., 1999. Processes controlling composition of heavy mineral assemblages. Sediment. Geol. 124, 3-29.

Nichols, G., Thompson, B., 2005. Bedrock lithology control on contemporaneous alluvial fan facies, Oligo-Miocene, Southern Pyrenees, Spain. Sedimentology 52, 571-585.

Nishikawa, T., Ito, M., 2000. Late Pleistocene barrier-island development reconstructed from genetic classification and timing of erosional surfaces, paleo-Tokyo Bay, Japan. Sediment. Geol. 137, 25-42.

Orton, G.J., Reading, H.G., 1993. Variability of deltaic processes in terms of sediment supply, with particular emphasis on grain size. Sedimentology 40, 475-512.
Parfenoff, A., Pomerol, C., Toureng, J., 1970. Les minéreux en grains, méthodes d'étude et détermination. Masson and Cie, Paris, France.

Peterson, C.D., Komar, P.D., Scheidegger, K.F., 1986. Distribution, geometries, and origin of heavy mineral placer deposits on Oregon Beachs. J. Sediment. Petrol. 56, 67-77.

Potró, M.N., 1995. Eventos tectonometamórficos pré-alpinos dos Alpes Orientais e do Maciço Hespérico-uma tentativa de correlação. Mem. Not., Publ. Mus. Lab. Mineral. Geol. Univ. Coimbra 119, 63-87.

Pureza, F.G., Araújo, A.M., 1956. Contribution à l'étude des sables du Nord du Portugal. Mem. Not., Publ. Mus. Lab. Mineral. Geol. Univ. Coimbra 42, 3-25.

Reis, R.P., Cunha, P.M., Barbosa, B., Antunes, M.T., Pais, J., 1992. Mainly continental Miocene and Pliocene deposits from lower Tagus and Mondego tertiary basins-Excursion B. Ciências da Terra, Spec., vol. 2, pp. 37-56.

Silva, C.M., 2001. Gastrópodes pliocénicos de Portugal. Sistemática, paleobiologia, paleoecologia e paleobiogeografia. $\mathrm{PhD}$ thesis, University of Lisbon, Portugal.

Soares, A.F., 1966. Estudo das formações pós-jurássicas da região de entre Sargento-Mor e Montemor-o-Velho. Mem. Not., Publ. Mus. Lab. Mineral. Geol. Univ. Coimbra 62, 1-343.

Soares, A.F., 1999. As unidades quaternárias e pliocénicas no espaço do Baixo Mondego (uma perspectiva de ordem). Estud. Quat. 2, $7-17$.

Soen, O.I., 1958. The geology, petrology and ore deposits of the Viseu region, Northern Portugal. Com. Serv. Geol. Portugal 4, 5-199.

Swift, D.J., Dill Jr., C.E., Mchone, J., 1971. Hydraulic fractionation of heavy mineral suites on an unconsolidated retreating coast. J. Sediment. Petrol. 41, 683-690.

Teichert, C., 1958. Concepts of facies. Bull. Am. Assoc. Pet. Geol. 42, 2718-2744.

Teixeira, C., Carvalho, L.H., Barros, R.F., Martins, J.A., Haas, W.E., Pilar, L., Rocha, A.T., 1961. Carta geológica de Portugal na escala 1/50000. Notícia explicativa da folha 17-C (Santa Comba Dão). Serviços Geológicos de Portugal, Lisbon, Portugal.

Thiel, G.A., 1945. Mechanical effects of stream transportation in mineral grains of sand size. Bull. Geol. Soc. Am. 56, 1207.

Walker, R.G., James, N.P. (Eds.), 1992. Facies Models: Response to Sea Level Change. Geological Association of Canada, Newfoundland, St. John. 